\title{
Petrography, geochemistry, and geochronology of the Sc-enriched Kiviniemi ferrodiorite intrusion, eastern Finland
}

\author{
Tapio Halkoaho ${ }^{1}$ (D) $\cdot$ Marjaana Ahven ${ }^{2} \cdot$ O. Tapani Rämö ${ }^{2} \cdot J_{a n n e ~ H o k k a}{ }^{3} \cdot$ Hannu Huhma $^{3}$
}

Received: 13 November 2018 / Accepted: 1 January 2020 / Published online: 23 January 2020

(C) The Author(s) 2020

\begin{abstract}
The Kiviniemi mafic intrusion, near the eastern margin of the Paleoproterozoic Central Finland Granitoid Complex, is both spatially and temporally associated with post-kinematic Fe-Ti-P-enriched Svecofennian orogenic mafic magmatism. The main rock types in this small $(\sim 15 \mathrm{ha})$ intrusion are garnet-bearing fayalite ferrodiorite, leucoferrodiorite, ferromonzodiorite, and pyroxene diorite. The garnet-bearing fayalite ferrodiorite and leucoferrodiorite contain 50-281 ppm Sc, 275-5600 ppm Zr, and 58-189 ppm Y $(n=42)$, delineating a mineralized deposit some 2.5 ha in extent. Overall, these rocks show an evolved (ironenriched) tholeiitic character; low values of $\mathrm{Ni}(<20-40 \mathrm{ppm}), \mathrm{Cr}(<20 \mathrm{ppm})$, and $\mathrm{Cu}(<20-80 \mathrm{ppm})$; and high contents of $\mathrm{Zn}$ (213-700 ppm). The rock-forming minerals in the ferrodioritic rocks are (ferro)hedenbergite, plagioclase $\left(\sim \mathrm{An}_{40}\right)$, ferropargasite and ferroedenite, almandine garnet, and fayalite $\left(\mathrm{Fo}_{1-4}\right)$. Accessory minerals include zircon, ilmenite, fluorapatite, biotite, pyrite, pyrrhotite, potassium feldspar, grunerite, and clinoferrosilite. Some relict cumulate textures have been preserved, but primary magmatic features have largely been overprinted by strong recrystallization and corona formation. The main carriers of Sc are amphibole, clinopyroxene, and apatite. The remarkably strong enrichment of Sc in ferromagnesian silicates and apatite, rather than in specific Sc-minerals, implies magmatic enrichment. Post-kinematic mafic intrusions in central Finland constitute a bimodal association with co-existing granitoid counterparts. The Kiviniemi mafic intrusion is associated with a coarse megacrystic granite and the two rock type display mingled contacts, indicative of contemporaneity of the two magmas. This conclusion is in accord with the coincident $\mathrm{U}-\mathrm{Pb}$ zircon ages for the ferrodiorite, at $1857 \pm 2 \mathrm{Ma}$ (multigrain ID-TIMS) and the megacrystic granite, at $1860 \pm 7 \mathrm{Ma}$ (single-crystal LA-MC-ICP-MS). The initial $\varepsilon \mathrm{Nd}$ value of the ferrodiorite and the granite are +0.1 and -2.5 , respectively. These $\mathrm{Nd}$ isotope compositions probably reflect a chondritic mantle source for the ferrodiorite and suggest incorporation of some Archaean crustal material into the granite in the course of magmatic evolution. The resource estimation calculated for Kiviniemi intrusion by using $40 \mathrm{~g} / \mathrm{t} \mathrm{Sc}$ cut off value is $13.4 \mathrm{Mt}$ of rock with an average grade of $162.7 \mathrm{~g} / \mathrm{t}$ scandium, $1726 \mathrm{~g} / \mathrm{t}$ zirconium, and $81 \mathrm{~g} / \mathrm{t}$ yttrium.
\end{abstract}

Keywords Ferrodiorite $\cdot$ Scandium $\cdot$ Zirconium $\cdot$ Yttrium $\cdot$ Bimodal $\cdot$ Svecofennian $\cdot$ Finland

Editorial handling: P. Peltonen

Electronic supplementary material The online version of this article (https://doi.org/10.1007/s00126-020-00952-2) contains supplementary material, which is available to authorized users.

Tapio Halkoaho

tapio.halkoaho@gtk.fi

1 Geological Survey of Finland, P.O. Box 1237, FI-70211 Kuopio, Finland

2 Department of Geosciences and Geography, Research Program in Geology and Geophysics, University of Helsinki, P.O. Box 64, FI-00014 Helsinki, Finland

3 Geological Survey of Finland, P.O. Box 96, FI-02151 Espoo, Finland

\section{Introduction}

Since the times of Bowen (1928) and Fenner (1929), strong iron enrichment in basaltic magmas has been acknowledged as a fundamental process of magmatic differentiation. The mechanisms of iron enrichment via the tholeiitic differentiation path may involve gravitational floating/accumulation, compositional convection, and segregation of an interstitial liquid (e.g., McBirney 1995; Mitchell et al. 1996; White 2007; Morse 2008), and liquid immiscibility (Philpotts 1979; Roedder 1978; Naslund 1983; Veksler 2009; Charlier and Grove 2012). As well as in layered mafic-ultramafic intrusions (e.g., Skaergaard, East Greenland; Bushveld, South Africa; Sept Iles, Canada), strong iron enrichment is observed 
in ferrodiorites and gabbroic rock suites of Proterozoic anorthosite complexes (e.g., Bolangir, India; Laramie, USA). The differentiation paths of anorthosite-related Fe-enriched magmas and some layered cumulate intrusions (e.g., Graveyard Point and Pleasant Bay, USA; Panzhihua, SW China; Grader, Canada) are explained by fractionation and formation of crystal "mush," from which iron-rich interstitial liquid is expelled. The residual interstitial liquids may crystallize laminar ferrogabbros and segregated granophyres, granophyric-enriched ferrodiorite, or oxide-rich cumulates and, subsequently, monzodiorite or ferrodiorite (e.g., Mitchell et al. 1996; Raith et al. 1997; Wiebe 1997; White 2007; Pang et al. 2008). Currently, the accumulation model is favored for Fe-Ti oxide (nelsonite) deposits (Charlier et al. 2008; Tollari et al. 2008). Liquid immiscibility in natural rocks is evidenced in lunar basalts and in the mesostasis of tholeiitic volcanic rocks and has also been experimentally studied (Hess et al. 1975; Philpotts 1982; Kontak et al. 2002; Thy et al. 2006; Veksler et al. 2007; Charlier and Grove 2012). Primary melt inclusion studies of apatite, olivine, plagioclase, and interstitial trapped melts as well as trace element geochemistry of cumulus apatite have also corroborated the concept of unmixing of late-stage liquids in mafic-layered intrusions (Jakobsen et al. 2005 and 2011; Charlier et al. 2011; VanTongeren and Mathez 2012).

Scandium is a commodity commonly associated with the rare earth elements (REE) and behaves as a compatible element in ferromagnesian rock-forming silicate systems. The abundance of $\mathrm{Sc}$ is, on average, $30-40 \mathrm{ppm}$ in mafic rocks and less than $20 \mathrm{ppm}$ in felsic rocks (Norman and Haskin 1968). Nine specific Sc-minerals have been documented; six of them are silicates (thortveitite, scandiobabingtonite, kristiansenite, bazzite, jervisite, and cascandite) and three are phosphates (juonniite, pretulite, and kolbeckite), and are typically found in hydrothermal vein systems and carbonatite complexes (Neumann 1961; Postl 1981; Mellini et al. 1982; Bergstøl and Juve 1988; Liferovich et al. 1998; Bernhard et al. 1998; Orlandi et al. 1998; Raade et al. 2002). Globally, economic-scale scandium deposits are mainly related to laterites and placers.

Besides Ni-Co laterite and placer type deposits (Jaireth et al. 2014), economic-grade Sc enrichment may be connected to hydrothermal processes by segregation of a melt rich in fluorides (Shchekina and Gramenitskii 2008). Graniterelated hydrothermal veins and metasomatic rocks such as albitite, greisen, and skarn are considered as the main hosts to Sc deposits. Rare Sc-silicates and phosphates as well as paragenetic Sc-rich heavy minerals have been documented from pegmatites and veins (Bergstøl and Juve 1988; Bernhard et al. 1998; Raade et al. 2002; Pezzotta et al. 2005). Several minerals, including aegirine, are known to enrich Sc during the formation of REE-deposits (Shimazaki et al. 2008). Carbonatites (Eby 1975; Åmli 1977; Liferovich et al. 1998) and weathering caps of alkaline carbonatite complexes (Kravchenko and Pokrovsky 1995) also host important scandium mineralizations, probably due to the stabilizing effect of carbonate complexes on Sc (Gramaccioli et al. 2000). Within the Svecofennian domain of the Fennoscandian shield, there occurs a distinct group of small Fe-Ti-P-enriched tholeiitic mafic-ultramafic intrusions that locally host small oxide deposits (e.g., Peltonen 2005). This paper deals with an Fe-TiP-enriched mafic intrusion located in the eastern part of the Svecofennian domain at Kiviniemi, in proximity to the Paleoproterozoic-Archean domain boundary. As well as with extreme iron enrichment, the Kiviniemi mafic intrusion is characterized by markedly elevated concentrations of $\mathrm{Sc}, \mathrm{Zr}$, and $\mathrm{Y}$. The Kiviniemi intrusion is described here in relation to mineralogy and geochemistry as well as tectonic setting and source constraints ( $\mathrm{U}-\mathrm{Pb}$ geochronology and $\mathrm{Sm}-\mathrm{Nd}$ isotopes). The major element geochemical composition of the intrusion, together with its close association with the surrounding granite, shows that it belongs to the post-kinematic Paleoproterozoic magmatic stage of the Svecofennian orogen. The trace element geochemical composition is consistent with a complex petrogenetic history. Overall, the Kiviniemi intrusion offers new insights into the origin and behavior of Sc in a highly evolved tholeiitic magma system. Very similar Scenriched intrusions to that at Kiviniemi Sc-deposit have been found at about the same time as Kiviniemi, in the year 2009, in Québec Province, Canada. These intrusions are also of interest as potential scandium deposits and consist of fayalite-bearing ferrosyenite; just as at Kiviniemi, scandium occurs in the crystal lattices of hedenbergite and amphibole (Daigle 2017).

\section{Geological setting}

The central and eastern parts of the Fennoscandian shield in Finland and adjacent Russia consist of Archean and Paleoproterozoic crustal domains (Fig. 1). The ca. 2.0 1.77 Ga Svecofennian orogeny, with major crust-forming events between 1.92 and $1.83 \mathrm{Ga}$, welded together the two domains along a complex geotectonic suture zone marked by overthickened crust (e.g., Nironen 1997; Korja et al. 2006; Baltybaev 2013; Lahtinen et al. 2014). Covering much of the Finnish part of the Paleoproterozoic domain, the 1.891.86 Ga Central Finland Granitoid Complex (CFGC) comprises synorogenic granitoids (granite, granodiorite, tonalite), fragments of supracrustal sequences, and some small maficultramafic intrusions. Nironen et al. (2000) divided the synorogenic granitoids into two groups: $1.89-1.88 \mathrm{Ga}$ synkinematic and 1.88-1.87 Ga post-kinematic, with an 
Fig. 1 Geological map of the Kiviniemi intrusion. Inset shows the principal geological features of the Fennoscandian shield and the location of Kiviniemi. A Archaean Kola-Karelian Domain, PP Paleoproterozoic (mainly Svecofennian) Domain, $C F G C$ Central Finland Granitoid Complex, $P H$ Phanerozoic rocks, $C$ Caledonides. Black pointed arrows show the direction of diamond drill holes

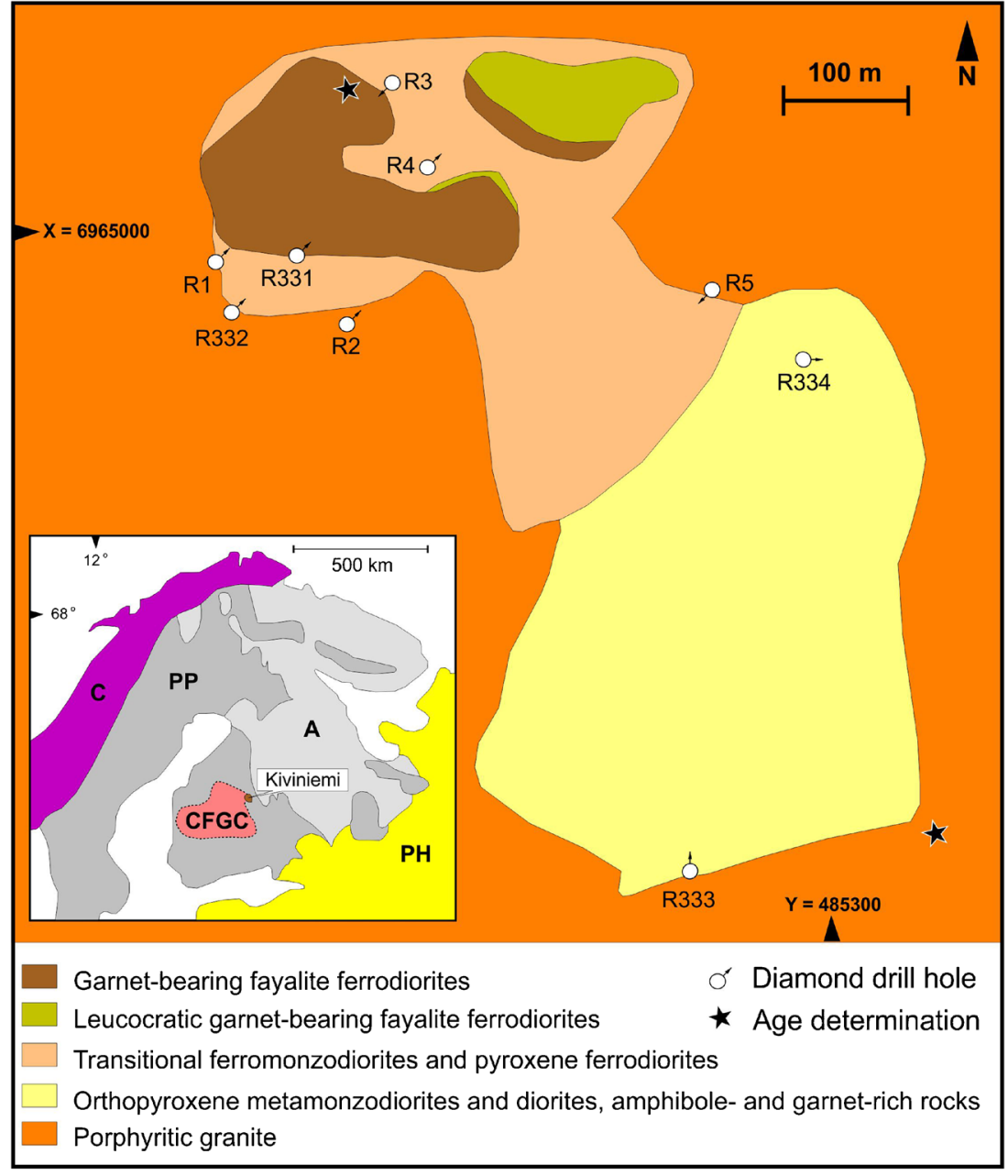

assumed spatial variation in age distribution, the oldest intrusions in the northeast and the youngest in the southwest. The majority of granites, granodiorites, and tonalites belong to the synkinematic group, while porphyritic quartz monzonites and some porphyritic granites are post-kinematic with respect to the main deformational events. The emplacement of the postkinematic intrusions was presumably controlled by crustal zones of weakness during transtensional or extensional stage after the main collisional events (Nironen et al. 2000; Nikkilä 2016). The post-kinematic granitoids display compositional variation from peraluminous to alkaline $\mathrm{C}$ - and A-type, and the small mafic bodies are considered to reflect bimodal magmatism, which is particularly characteristic of A-type granite suites (Nironen et al. 2000; Peltonen 2005).

Fe-Ti-P-enriched mafic intrusions in the western parts of the CFGC area (post-kinematic and synorogenic) include a quartz diorite-wehrlite layered intrusion, ilmenite gabbros, and apatite-ilmenite-magnetite gabbros (Rämö 1986; Kärkkäinen and Appelqvist 1999; Rämö et al. 2001;
Kärkkäinen and Bornhorst 2003). In the eastern parts of the $\mathrm{CFGC}$, the focus of exploration has been on $\mathrm{Ni}-\mathrm{Cu}$-enriched intrusions along the Proterozoic-Archaean boundary zone (Barnes et al. 2009). In general, the small mafic intrusions of the area are amphibole- and pyroxene-bearing gabbros and diorites; rare ultramafic rocks are present as inclusions or as small igneous bodies. Contact zones are often brecciated and may also show mingling features with the surrounding lithologic units (Pääjärvi 2000). Our target, the Kiviniemi mafic intrusion (Fig. 1), displays many of these characteristics on outcrop scale, but has some strikingly deviating geochemical and mineralogical features that set the intrusion apart from other Svecofennian mafic intrusions of the CFGC area.

\section{Sampling and methods}

Bedrock mapping and geophysical field measurements at Kiviniemi were initiated by the Geological Survey of 
Finland (GTK) in 2008. Nine drill holes (total $1251.80 \mathrm{~m}$ ) were drilled into the mafic intrusion, five of which intersected the strongly Sc-enriched ferrodiorites (Fig. 1). Samples from the nine drill cores $(n=67)$ and 47 outcrops $(n=8$, including 2 samples from the surrounding megacrystic granite) were analyzed in Finland by Labtium Ltd. for their whole rock composition. The X-ray fluorescence method (XRF; $n=75$, Labtium Ltd., analytical method $175 \mathrm{X}$, pressed powder pellet-XRF) was used for major elements and the following trace elements: S, Cl, Sc, V, Cr, Ni, Cu, Zn, Ga, As, Rb, Sr, Y, Zr, $\mathrm{Nb}, \mathrm{Mo}, \mathrm{Sn}, \mathrm{Sb}, \mathrm{Ba}, \mathrm{La}, \mathrm{Ce}, \mathrm{Pb}, \mathrm{Bi}, \mathrm{Th}$, and U. Rare earth and other elements such as Ce, Dy, Er, Eu, Gd, Hf, Ho, La, Lu, Nb, $\mathrm{Nd}, \mathrm{Pr}, \mathrm{Rb}, \mathrm{Sc}, \mathrm{Sm}, \mathrm{Ta}, \mathrm{Tb}, \mathrm{Th}, \mathrm{Tm}, \mathrm{U}, \mathrm{V}, \mathrm{Y}, \mathrm{Yb}$. and $\mathrm{Zr}$ as well as $\mathrm{Co}$ from an additional 14 samples were measured with inductively coupled plasma mass spectrometry (ICP-MS; $n=$ 30, Labtium Ltd., Analytical Method $308 \mathrm{M}$, involving HF$\mathrm{HClO}_{4}$-digestion and lithium metaborate-sodium perborate fusion). The laboratory uses measurement methods that are validated for similar matrices and the calculation method uses isotope and matrix specified interference correction equations (Susanna Arvilommi, Labtium Ltd. 2019, personal communication). All analyzed element contents in the ICP-MS analyses were above their detection limits. For detailed description of the analytical procedures, see Rasilainen et al. (2007). Where an element was analyzed both methods (XRF and ICP-MS), the more precise ICP-MS analysis is presented in Table 1 and the supplementary Table 2 (Appendix II). In Fig. 9, scandium, yttrium, and zirconium values, and in Fig. 10, scandium values were determined by ICP-OES from solutions after sodium peroxide fusion of $0.2 \mathrm{~g}$ samples in a $\mathrm{Ni}$ crucible (Labtium Ltd., analytical method 724P). The detection limits for those elements are 20,10 , and $50 \mathrm{mg} / \mathrm{kg}$, respectively. Plotting of the geochemical data was done using the Geochemical Data Toolkit (GCDkit) software. Polished thin sections $(n=51)$ were used to determine the compositions of the main minerals, their alteration products, and the main Sc carriers. Silicate, oxide, phosphate, and carbonate analyses from 17 thin sections were carried out at the GTK Otaniemi Research Laboratory, Espoo, using a Cameca SX100 electron microprobe. Standard analytical conditions included an acceleration voltage of $15 \mathrm{kV}$, beam current $20 \mathrm{nA}$, and beam diameter $5 \mu \mathrm{m}$ for silicates, oxides, and apatites, and $15 \mathrm{kV}$, beam current $10 \mathrm{nA}$, and beam diameter $10 \mu \mathrm{m}$ for carbonates. The practical detection limit in these routine analyses varies from $51 \mathrm{ppm}(\mathrm{Sc})$ to $2024 \mathrm{ppm}(\mathrm{Zn}$ ) (see Supplementary Material Appendix_I_mineral_analyses). Analyzed peaks and standards used in mineral analyses were as follows: $\mathrm{Si} \mathrm{Ka}, \mathrm{Mg} \mathrm{Ka}$, and $\mathrm{Ca} \mathrm{Ka}$ (diopside), $\mathrm{Al} \mathrm{Ka}$ and $\mathrm{Fe}$ $\mathrm{Ka}$ (almandine), Ti Ka (rutile), $\mathrm{Cr} \mathrm{Ka}$ (chromite), V Ka (V, synthetic 100 wt $\%$ metal), $\mathrm{Mn} \mathrm{Ka}$ (rhodonite), $\mathrm{Na} \mathrm{Ka}$ and $\mathrm{Cl}$ $\mathrm{Ka}$ (tugtupite), $\mathrm{K} \mathrm{Ka}$ (sanidine), $\mathrm{Sr} \mathrm{La}$ (celestine), Ba La (barite), Ni Ka and S Ka (pentlandite), Zn Ka (sphalerite), P $\mathrm{Ka}$ (apatite), F Ka (fluorite), $\mathrm{Pb} \mathrm{La}$ (galena), $\mathrm{Sc} \mathrm{Ka}$ (Sc, synthetic $100 \mathrm{wt} \%$ metal), $\mathrm{Zr} \mathrm{La}$ (synthetic cubic zirconia), $\mathrm{Hf} \mathrm{La}$ (Hf, synthetic $100 \mathrm{wt} \%$ metal), Y La (YAG, synthetic Y-Algarnet), and Th $\mathrm{Ma}$ (Th, synthetic $100 \mathrm{wt} \%$ metal). Sc, V, Hf, and Th are synthetic $100 \mathrm{wt} \%$ metals, $\mathrm{Zr}$ synthetic cubic zirconia, and Y synthetic Y-Al-garnet; all others are naturally occurring minerals. Selected main mineral analyses are presented in Table 2. Zircon U-Pb age determinations were carried out at the GTK. Mineral fractions were separated in the GTK Research Laboratory. Mass spectrometry based on thermal ionization (ID-TIMS using a VG Sector 54 mass spectrometer) was used for the ferrodiorite, and the laser ablation multicollector method (LA-MC-ICP-MS) for the surrounding megacrystic granite (for sample locations, see Fig. 1). LA-MC-ICP-MS analyses were carried out using $\mathrm{Nu}$ Plasma HR multicollector equipment without shutter mode. Standards A1772 (2712 Ma) and GJ1 (609 Ma) were used for calibration and sample A382 with a well-known age (1877 \pm $2 \mathrm{Ma}$ ) was used as a control sample. Detailed description of analytical methods can be found in Huhma et al. (2012a). Age calculations and plotting of the $\mathrm{U}-\mathrm{Pb}$ data were done using the Isoplot/ Ex 3 program of Ludwig (2003).

Whole-rock Sm-Nd analyses were performed using IDTIMS following the standard procedures at GTK (e.g., Huhma et al. 2012b). Initial $\varepsilon N d$ was calculated using the decay constant $\lambda^{147} \mathrm{Sm}=6.54 * 10^{-12} \mathrm{a}^{-1}$ (Steiger and Jäger 1977) and chondritic isotopic ratios of ${ }^{147} \mathrm{Sm} /{ }^{144} \mathrm{Nd}=0.1966$ and ${ }^{143} \mathrm{Nd} /{ }^{144} \mathrm{Nd}=0.512640$ (DePaolo and Wasserburg 1976).

\section{Results}

\section{Field and drill core observations}

The Kiviniemi mafic intrusion has a total area of 15 ha and includes a 2.5 ha Sc-Zr-Y mineralized rock and in addition a small satellite body, surrounded by various dioritic rock units (Fig. 1). Medium- to coarse-grained, garnet-bearing fayalite ferrodiorite forms the main deposit and the north-eastern satellite body (Figs. 1 and 2a). Leucocratic ferrodiorites and a few two-meter-thick fayalite pyroxenite cumulate layers are found in close contact with the main deposit rocks. Locally, orthopyroxene- and garnet-bearing granitoid dikes $(\leq 3 \mathrm{~m})$ transect the main deposit.

A heterogeneous, compositionally transitional group of medium- to fine-grained dioritic and monzodioritic rocks (referred to here as heterogeneous diorites) extends some $500 \mathrm{~m}$ south and southeast of the main deposit (Fig. 1). The composition of the heterogeneous diorites varies from fayalite- 
Table 1 Representative chemical compositions from the Kiviniemi mafic intrusion and surrounding megacrystic granite

\begin{tabular}{|c|c|c|c|c|c|c|}
\hline $\begin{array}{l}\text { XRF + } \\
\text { ICP-MS } \\
\text { Sample }\end{array}$ & $\begin{array}{l}\text { R331 6.60-7.05 m } \\
\text { Fayalite pyroxenite } \\
\text { cumulate }\end{array}$ & $\begin{array}{l}\text { R331 } 49.20-49.45 \mathrm{~m} \\
\text { Garnet-bearing fayalite } \\
\text { ferrodiorite }\end{array}$ & $\begin{array}{l}\text { R3 } 59.50-61.00 \mathrm{~m} \\
\text { Garnet-bearing fayalite } \\
\text { ferrodiorite }\end{array}$ & $\begin{array}{l}\text { R4 } 127.00- \\
128.50 \mathrm{~m} \\
\text { Leucocratic } \\
\text { ferrodiorite }\end{array}$ & $\begin{array}{l}\text { R5 56.00-57.00 m } \\
\text { Metaferromonzodiorite }\end{array}$ & $\begin{array}{l}\text { R333 26.00- } \\
26.25 \mathrm{~m} \\
\text { Pyroxene } \\
\text { diorite }\end{array}$ \\
\hline $\mathrm{SiO}_{2}(\mathrm{wt} \%)$ & 34.20 & 41.10 & 46.70 & 51.60 & 46.40 & 48.00 \\
\hline $\mathrm{TiO}_{2}$ & 3.06 & 2.12 & 1.62 & 1.34 & 2.11 & 3.54 \\
\hline $\mathrm{Al}_{2} \mathrm{O}_{3}$ & 2.75 & 11.10 & 12.90 & 16.30 & 13.10 & 14.90 \\
\hline $\mathrm{FeO}_{\text {tot }}$ & 37.70 & 26.54 & 20.97 & 13.23 & 18.63 & 13.68 \\
\hline $\mathrm{MnO}$ & 0.76 & 0.51 & 0.39 & 0.24 & 0.30 & 0.19 \\
\hline $\mathrm{MgO}$ & 1.81 & 0.81 & 0.96 & 0.84 & 1.61 & 3.03 \\
\hline $\mathrm{CaO}$ & 10.04 & 8.93 & 7.09 & 6.77 & 7.04 & 7.57 \\
\hline $\mathrm{Na}_{2} \mathrm{O}$ & 0.6 & 1.93 & 2.59 & 3.41 & 2.62 & 2.86 \\
\hline $\mathrm{K}_{2} \mathrm{O}$ & 0.314 & 1.53 & 2.97 & 3.32 & 3.03 & 2.35 \\
\hline $\mathrm{P}_{2} \mathrm{O}_{5}$ & 1.22 & 1.03 & 0.69 & 0.61 & 1.05 & 1.86 \\
\hline Total & 92.46 & 95.61 & 96.88 & 97.66 & 95.88 & 97.97 \\
\hline Mg\# & 8.7 & 5.7 & 8.3 & 11.2 & 14.6 & 30.5 \\
\hline $\mathrm{Ba}(\mathrm{ppm})$ & 160 & 1420 & 2797 & 2203 & 2042 & 1050 \\
\hline $\mathrm{Rb}$ & 60 & $36.3^{\mathrm{a}}$ & $75.8^{\mathrm{a}}$ & $78.4^{\mathrm{a}}$ & $61.1^{\mathrm{a}}$ & 80 \\
\hline $\mathrm{Sr}$ & 40 & 210 & 287 & 374 & 284 & 350 \\
\hline $\mathrm{Pb}$ & $<30$ & $<30$ & $<20$ & $<20$ & $<20$ & $<30$ \\
\hline $\mathrm{Cr}$ & $<30$ & $<30$ & $<20$ & $<20$ & $<20$ & $<30$ \\
\hline $\mathrm{Ni}$ & 30 & 30 & $<20$ & $<20$ & 20 & 40 \\
\hline $\mathrm{Co}^{\mathrm{a}}$ & - & 3.77 & - & - & - & - \\
\hline $\mathrm{Cu}$ & 70 & 40 & 31 & 22 & 31 & 40 \\
\hline $\mathrm{Zn}$ & 780 & 470 & 449 & 363 & 448 & 210 \\
\hline $\mathrm{Ga}$ & 30 & 30 & 30 & 30 & 28 & 30 \\
\hline $\mathrm{Sc}$ & 210 & $281^{\mathrm{a}}$ & $219^{\mathrm{a}}$ & $59.5^{\mathrm{a}}$ & $67.2^{\mathrm{a}}$ & 30 \\
\hline $\mathrm{Zr}$ & 710 & $894^{\mathrm{a}}$ & $298^{\mathrm{a}}$ & $1340^{\mathrm{a}}$ & $1120^{\mathrm{a}}$ & 490 \\
\hline V & 100 & $2.12^{\mathrm{a}}$ & $0.5^{\mathrm{a}}$ & $12^{\mathrm{a}}$ & $14.9^{\mathrm{a}}$ & 160 \\
\hline $\mathrm{Th}$ & $<10$ & $1.11^{\mathrm{a}}$ & $1.12^{\mathrm{a}}$ & $1.66^{\mathrm{a}}$ & $1.05^{\mathrm{a}}$ & $<10$ \\
\hline $\mathrm{U}$ & $<10$ & $0.29^{\mathrm{a}}$ & $0.27^{\mathrm{a}}$ & $0.99^{\mathrm{a}}$ & $0.46^{\mathrm{a}}$ & $<10$ \\
\hline Y & 130 & $82^{\mathrm{a}}$ & $83.6^{\mathrm{a}}$ & $96.1^{\mathrm{a}}$ & $134^{\mathrm{a}}$ & 50 \\
\hline $\mathrm{Hf}^{\mathrm{a}}$ & - & 19.6 & 8.67 & 30.6 & 25.8 & - \\
\hline $\mathrm{Y}$ & 130 & $82^{\mathrm{a}}$ & $83.6^{\mathrm{a}}$ & $96.1^{\mathrm{a}}$ & $134^{\mathrm{a}}$ & 50 \\
\hline $\mathrm{Nb}$ & $<7$ & $19^{\mathrm{a}}$ & $33.8^{\mathrm{a}}$ & $63.9^{\mathrm{a}}$ & $79.8^{\mathrm{a}}$ & 20 \\
\hline $\mathrm{Ta}^{\mathrm{a}}$ & - & 0.85 & 1.93 & 3.07 & 3.58 & - \\
\hline $\mathrm{La}$ & 70 & $42.6^{\mathrm{a}}$ & $56^{\mathrm{a}}$ & $75.2^{\mathrm{a}}$ & $91.3^{\mathrm{a}}$ & 70 \\
\hline $\mathrm{Ce}$ & 210 & $106^{\mathrm{a}}$ & $134^{\mathrm{a}}$ & $173^{\mathrm{a}}$ & $227^{\mathrm{a}}$ & 160 \\
\hline $\operatorname{Pr}^{\mathrm{a}}$ & - & 15.9 & 19.1 & 24 & 33.7 & - \\
\hline $\mathrm{Nd}^{\mathrm{a}}$ & - & 79.9 & 88.7 & 106 & 155 & - \\
\hline $\mathrm{Sm}^{\mathrm{a}}$ & - & 18.7 & 20.6 & 23.6 & 34.8 & - \\
\hline $\mathrm{Eu}^{\mathrm{a}}$ & - & 3.76 & 5.57 & 6.1 & 5.64 & - \\
\hline $\mathrm{Gd}^{\mathrm{a}}$ & - & 19.4 & 21.4 & 23.4 & 35.1 & - \\
\hline $\mathrm{Tb}^{\mathrm{a}}$ & - & 2.8 & 3.11 & 3.45 & 5.07 & - \\
\hline $\mathrm{Dy}^{\mathrm{a}}$ & - & 15.6 & 17.8 & 20.5 & 29.5 & - \\
\hline $\mathrm{Ho}^{\mathrm{a}}$ & - & 2.9 & 3.46 & 3.88 & 5.5 & - \\
\hline $\mathrm{Er}^{\mathrm{a}}$ & - & 7.86 & 9.62 & 11.1 & 15.1 & - \\
\hline $\mathrm{Tm}^{\mathrm{a}}$ & - & 1.08 & 1.37 & 1.58 & 2.09 & - \\
\hline $\mathrm{Yb}^{\mathrm{a}}$ & - & 7.79 & 9.16 & 10.6 & 13.4 & - \\
\hline $\mathrm{Lu}^{\mathrm{a}}$ & - & 1.22 & 1.47 & 1.7 & 2.07 & - \\
\hline
\end{tabular}

${ }^{\text {a }}$ ICP-MS, others XRF 
bearing pyroxene monzodiorite to pyroxene diorite. Strongly metamorphosed diorites and garnet-rich rocks are found near the eastern border of the intrusion. The strike of the preferred orientation of the diorites is broadly parallel to the NW-SE faulting, which is a commonly observed feature in the vicinity of the study area.

The mafic intrusion is surrounded by a megacrystic granite (Figs. 1 and 2b). Potassium feldspar megacrysts are 1-8 $\mathrm{cm}$ long, euhedral, lath-shaped, and display an orientation that is concordant with the margins of the mafic body. Toward the north and west, the megacrystic granite grades into granodiorite. The eastern border of the megacrystic granite is cut by a microcline granite related to NW-SE faulting (Pääjärvi 2000).

\section{Petrography and mineralogy}

\section{Kiviniemi mafic intrusion}

\section{Ferrodiorites and leucoferrodiorites}

The ferrodioritic rocks, including ferrodiorite and leucoferrodiorite, are characterized by strong variation in color index and also by some differences in chemical composition (see below). In addition to plagioclase $\left(\mathrm{An}_{26-45}\right.$, average $\mathrm{An}$ content ca. $40 \mathrm{~mol} \%)$, the main (>10 vol.\%) minerals are (ferro)hedenbergitic clinopyroxene, almandine garnet, fayalitic olivine $\left(\mathrm{Fo}_{1-4}\right)$, and amphiboles (ferropargasite and ferroedenite). Selected main mineral analyses are presented in Table 2 . Accessory minerals (0-10\%) include ilmenite, fluorapatite $(\sim 5 \%)$, zircon, magnetite, biotite, pyrite, and pyrrhotite. Some accessory interstitial quartz and microcline are present, sporadic larger potassium feldspar grains are xenocrysts incorporated from the surrounding granite (Fig. 2c). The ferrodiorites contain, on average, $0-5 \%$ of CIPW-normative quartz.

Reaction rims are abundant in the ferrodiorites and leucoferrodiorites (Fig. 3a-g). Clusters of mafic minerals (Fig. 3c) are rimmed by small amphibole grains and/or lacelike garnet. Fayalite pyroxenite layers show a mesocumulate texture with clinopyroxene, fayalite, apatite, and Fe-Ti-oxides as cumulus minerals, and feldspars constituting the intercumulus phase. Accessory zircon forms euhedral grains up to $0.6 \mathrm{~mm}$ in diameter (Fig. $3 \mathrm{~d}$ ) and some minute garnet grains are also present.

The most common accessory mineral in the ferrodiorites is ilmenite. It occurs interstitially in the groundmass, as inclusions, exsolution lamellae, and skeletal grain aggregates together with minor magnetite, hematite, pyrite, and pyrrhotite. Euhedral zircon (Fig. 3f) and apatite are
Table 2 Selected microprobe analyses of main silicate minerals from the Kiviniemi area. $\mathrm{mg} \#=100 \mathrm{Mg} /\left(\mathrm{Mg}+\mathrm{Fe}^{2+}+\mathrm{Mn}\right)$. Total $\mathrm{Fe}$ as $\mathrm{FeO}$

Olivines

\begin{tabular}{lrrrr} 
& \multicolumn{1}{c}{1} & \multicolumn{1}{c}{2} & \multicolumn{1}{c}{3} & \multicolumn{1}{c}{4} \\
$\mathrm{SiO}_{2}$ & 30.27 & 30.00 & 30.23 & 30.00 \\
$\mathrm{FeO}_{\text {tot }}$ & 66.69 & 66.31 & 66.60 & 63.49 \\
$\mathrm{MnO}$ & 1.60 & 1.83 & 1.86 & 3.47 \\
$\mathrm{MgO}$ & 1.40 & 0.84 & 1.27 & 0.35 \\
$\mathrm{NiO}$ & $<0.04$ & $<0.04$ & $<0.04$ & $<0.04$ \\
Total & 99.95 & 98.99 & 99.96 & 97.31
\end{tabular}

Numbers of ions on the basis of $4(\mathrm{O})$

$\begin{array}{lllll}\mathrm{Si} & 1.011 & 1.015 & 1.011 & 1.030 \\ \mathrm{Fe}^{2+} & 1.863 & 1.876 & 1.863 & 1.822 \\ \mathrm{Mn} & 0.045 & 0.052 & 0.053 & 0.101 \\ \mathrm{Mg} & 0.070 & 0.043 & 0.063 & 0.018 \\ \mathrm{Ni} & 0.000 & 0.000 & 0.000 & 0.000 \\ \mathrm{Fo} & 3.5 & 2.2 & 3.2 & 0.9\end{array}$

$1=\mathrm{R} 2163.50 \mathrm{~m}$ (fayalite ferrodiorite)

$2=\mathrm{R} 314.50 \mathrm{~m}$ (ferrodiorite)

$3=\mathrm{R} 359.65 \mathrm{~m}$ (fayalite ferrodiorite)

$4=\mathrm{R} 467.10 \mathrm{~m}$ (fayalite ferrodiorite)

$5=\mathrm{R} 3333.7 \mathrm{~m}$ (ferrodiorite)

$6=\mathrm{R} 33417.20 \mathrm{~m}$ (ferrodiorite)

$7=\mathrm{R} 210.50 \mathrm{~m}$ (megacrystic granite)

$8=$ R2 $238.00 \mathrm{~m}$ (fayalite leucoferrodiorite)

$9=\mathrm{R} 33144.70 \mathrm{~m}$ (fayalite ferrodiorite)

Amphiboles

\begin{tabular}{lrrrr} 
& \multicolumn{1}{c}{1} & \multicolumn{1}{c}{2} & \multicolumn{1}{c}{3} & \multicolumn{1}{c}{4} \\
$\mathrm{SiO}_{2}$ & 39.67 & 38.95 & 39.73 & 39.29 \\
$\mathrm{TiO}_{2}$ & 1.66 & 2.23 & 1.50 & 2.26 \\
$\mathrm{Al}_{2} \mathrm{O}_{3}$ & 11.65 & 10.43 & 10.23 & 10.65 \\
$\mathrm{FeO}_{\text {tot }}$ & 28.55 & 30.74 & 30.25 & 29.63 \\
$\mathrm{MnO}$ & 0.31 & 0.30 & 0.38 & 0.43 \\
$\mathrm{MgO}$ & 2.51 & 1.13 & 2.02 & 1.12 \\
$\mathrm{CaO}$ & 10.74 & 10.43 & 10.61 & 10.46 \\
$\mathrm{Na} 2 \mathrm{O}$ & 1.27 & 1.50 & 1.29 & 1.44 \\
$\mathrm{~K}_{2} \mathrm{O}$ & 1.76 & 1.67 & 1.46 & 1.52 \\
$\mathrm{Sc}_{2} \mathrm{O}_{3}$ & 0.17 & 0.06 & 0.18 & 0.08 \\
$\mathrm{Total}$ & 98.28 & 97.44 & 97.67 & 96.87
\end{tabular}

Numbers of ions on the basis of $24(\mathrm{O}, \mathrm{OH}, \mathrm{F}, \mathrm{Cl})$

$\begin{array}{lllll}\mathrm{Si} & 6.319 & 6.348 & 6.425 & 6.396 \\ \mathrm{Ti} & 0.198 & 0.273 & 0.183 & 0.277 \\ \mathrm{Al} & 2.186 & 2.004 & 1.950 & 2.043 \\ \mathrm{Fe}^{2+} & 3.804 & 4.191 & 4.091 & 4.034 \\ \mathrm{Mn} & 0.042 & 0.041 & 0.052 & 0.060 \\ \mathrm{Mg} & 0.596 & 0.275 & 0.487 & 0.271 \\ \mathrm{Ca} & 1.833 & 1.821 & 1.839 & 1.824 \\ \mathrm{Na} & 0.393 & 0.474 & 0.405 & 0.455 \\ \mathrm{~K} & 0.358 & 0.347 & 0.301 & 0.315\end{array}$


Table 2 (continued)

\begin{tabular}{|c|c|c|c|c|c|c|c|c|c|}
\hline \multirow{2}{*}{$\begin{array}{l}\mathrm{Sc} \\
\mathrm{mg \#}\end{array}$} & \multirow{2}{*}{$\begin{array}{l}0.023 \\
13.4\end{array}$} & \multirow{2}{*}{$\begin{array}{l}0.008 \\
6.1\end{array}$} & \multirow{2}{*}{$\begin{array}{l}0.026 \\
10.5\end{array}$} & \multirow{2}{*}{$\begin{array}{l}0.011 \\
6.2\end{array}$} & \multicolumn{5}{|c|}{ Numbers of ions on the basis of $32(\mathrm{O})$} \\
\hline & & & & & $\mathrm{Si}$ & 10.289 & 10.917 & 10.489 & 10.337 \\
\hline \multicolumn{5}{|c|}{ Clinopyroxenes } & $\mathrm{Al}$ & 5.698 & 5.087 & 5.498 & 5.649 \\
\hline & 1 & 2 & 3 & 4 & $\mathrm{Fe} 2+$ & 0.009 & 0.027 & 0.009 & 0.013 \\
\hline $\mathrm{SiO}_{2}$ & 49.02 & 47.89 & 48.63 & 48.69 & $\mathrm{Ca}$ & 1.786 & 1.156 & 1.545 & 1.674 \\
\hline $\mathrm{TiO}_{2}$ & 0.16 & 0.10 & 0.14 & 0.08 & $\mathrm{Na}$ & 2.119 & 2.663 & 2.401 & 2.271 \\
\hline $\mathrm{Al}_{2} \mathrm{O}_{3}$ & 1.20 & 1.03 & 1.02 & 0.58 & $\mathrm{~K}$ & 0.026 & 0.025 & 0.023 & 0.041 \\
\hline $\mathrm{FeO}_{\text {tot }}$ & 25.88 & 27.70 & 26.14 & 28.24 & $\mathrm{Sr}$ & 0.000 & 0.000 & 0.000 & 0.000 \\
\hline $\mathrm{MnO}$ & 0.65 & 0.53 & 0.74 & 0.98 & An & 45.4 & 30.1 & 38.9 & 42.0 \\
\hline $\mathrm{MgO}$ & 3.55 & 1.72 & 3.08 & 1.62 & $\mathrm{Ab}$ & 53.9 & 69.3 & 60.5 & 57.0 \\
\hline $\mathrm{CaO}$ & 19.43 & 19.84 & 19.21 & 19.12 & Or & 0.7 & 0.6 & 0.6 & 1.0 \\
\hline $\mathrm{Na}_{2} \mathrm{O}$ & 0.24 & 0.22 & 0.17 & 0.20 & Potassium fe & & & & \\
\hline $\mathrm{Sc}_{2} \mathrm{O}_{3}$ & 0.17 & 0.09 & 0.13 & 0.11 & & 1 & 2 & 3 & \\
\hline Total & 100.29 & 99.12 & 99.27 & 99.62 & $\mathrm{SiO}_{2}$ & 64.57 & 64.11 & 62.72 & \\
\hline \multicolumn{5}{|c|}{ Numbers of ions on the basis of $6(\mathrm{O})$} & $\mathrm{A} 12 \mathrm{O} 3$ & 18.56 & 18.38 & 18.55 & \\
\hline $\mathrm{Si}$ & 1.974 & 1.976 & 1.983 & 1.999 & FeOtot & 0.37 & 0.03 & 0.78 & \\
\hline $\mathrm{Ti}$ & 0.005 & 0.003 & 0.004 & 0.002 & $\mathrm{CaO}$ & 0.09 & 0.03 & 0.03 & \\
\hline Al & 0.057 & 0.050 & 0.049 & 0.028 & $\mathrm{Na}_{2} \mathrm{O}$ & 0.89 & 0.82 & 1.09 & \\
\hline $\mathrm{Fe}^{2+}$ & 0.871 & 0.956 & 0.891 & 0.970 & $\mathrm{~K}_{2} \mathrm{O}$ & 14.86 & 14.93 & 13.63 & \\
\hline $\mathrm{Mn}$ & 0.022 & 0.019 & 0.026 & 0.034 & $\mathrm{SrO}$ & $<0.11$ & $<0.11$ & $<0.11$ & \\
\hline $\mathrm{Mg}$ & 0.213 & 0.106 & 0.187 & 0.099 & Total & 99.38 & 98.30 & 96.82 & \\
\hline $\mathrm{Ca}$ & 0.838 & 0.877 & 0.839 & 0.841 & \multicolumn{5}{|c|}{ Numbers of ions on the basis of $32(\mathrm{O})$} \\
\hline $\mathrm{Na}$ & 0.019 & 0.017 & 0.013 & 0.016 & $\mathrm{Si}$ & 11.962 & 11.990 & 11.899 & \\
\hline $\mathrm{Sc}$ & 0.002 & 0.001 & 0.002 & 0.001 & $\mathrm{Al}$ & 4.053 & 4.052 & 4.147 & \\
\hline Wo & 43.1 & 44.8 & 43.2 & 43.3 & $\mathrm{Fe} 2+$ & 0.057 & 0.005 & 0.124 & \\
\hline En & 11.0 & 5.4 & 9.6 & 5.1 & $\mathrm{Ca}$ & 0.018 & 0.006 & 0.005 & \\
\hline Fs & 45.9 & 49.8 & 47.2 & 51.6 & $\mathrm{Na}$ & 0.320 & 0.299 & 0.400 & \\
\hline \multicolumn{5}{|c|}{ Orthopyroxenes } & $\mathrm{K}$ & 3.513 & 3.562 & 3.300 & \\
\hline & 5 & 6 & 7 & & $\mathrm{Sr}$ & 0.000 & 0.000 & 0.000 & \\
\hline $\mathrm{SiO}_{2}$ & 49.74 & 49.81 & 47.85 & & An & 0.5 & 0.2 & 0.1 & \\
\hline $\mathrm{TiO}_{2}$ & 0.06 & 0.06 & 0.07 & & $\mathrm{Ab}$ & 8.3 & 7.7 & 10.8 & \\
\hline $\mathrm{Al}_{2} \mathrm{O}_{3}$ & 0.49 & 0.63 & 0.43 & & Or & 91.2 & 92.1 & 89.1 & \\
\hline $\mathrm{FeO}_{\text {tot }}$ & 37.06 & 36.46 & 40.32 & & Garnets & & & & \\
\hline $\mathrm{MnO}$ & 0.76 & 0.73 & 1.24 & & & 1 & 8 & 9 & \\
\hline $\mathrm{MgO}$ & 11.75 & 12.33 & 8.51 & & $\mathrm{SiO}_{2}$ & 37.64 & 37.42 & 37.19 & \\
\hline $\mathrm{CaO}$ & 0.73 & 0.71 & 0.89 & & $\mathrm{Al}_{2} \mathrm{O}_{3}$ & 20.33 & 19.84 & 20.20 & \\
\hline $\mathrm{Na}_{2} \mathrm{O}$ & $<0.05$ & $<0.05$ & $<0.05$ & & $\mathrm{FeO}_{\text {tot }}$ & 33.11 & 32.57 & 31.65 & \\
\hline $\mathrm{Sc}_{2} \mathrm{O}_{3}$ & $<0.03$ & $<0.03$ & $<0.03$ & & $\mathrm{MnO}$ & 2.07 & 1.55 & 2.01 & \\
\hline Total & 100.59 & 100.75 & 99.32 & & $\mathrm{MgO}$ & 0.51 & 0.46 & 0.33 & \\
\hline \multicolumn{5}{|c|}{ Numbers of ions on the basis of $6(\mathrm{O})$} & $\mathrm{CaO}$ & 7.55 & 8.59 & 8.36 & \\
\hline $\mathrm{Si}$ & 1.985 & 1.978 & 1.980 & & Total & 101.26 & 100.54 & 99.80 & \\
\hline $\mathrm{Ti}$ & 0.002 & 0.002 & 0.002 & & \multicolumn{5}{|c|}{ Numbers of ions on the basis of $24(\mathrm{O})$} \\
\hline Al & 0.023 & 0.030 & 0.021 & & $\mathrm{Si}$ & 6.040 & 6.047 & 6.039 & \\
\hline $\mathrm{Fe}^{2+}$ & 1.237 & 1.211 & 1.395 & & $\mathrm{Al}$ & 3.844 & 3.778 & 3.867 & \\
\hline $\mathrm{Mn}$ & 0.026 & 0.025 & 0.044 & & $\mathrm{Mg}$ & 0.123 & 0.112 & 0.079 & \\
\hline $\mathrm{Mg}$ & 0.699 & 0.730 & 0.525 & & $\mathrm{Fe}^{2+}$ & 4.443 & 4.401 & 4.298 & \\
\hline $\mathrm{Ca}$ & 0.031 & 0.030 & 0.039 & & $\mathrm{Mn}$ & 0.281 & 0.212 & 0.276 & \\
\hline $\mathrm{Na}$ & 0.000 & 0.000 & 0.000 & & $\mathrm{Ca}$ & 1.297 & 1.488 & 1.454 & \\
\hline $\mathrm{Sc}$ & 0.000 & 0.000 & 0.000 & & Pyrope & 2.0 & 1.8 & 1.3 & \\
\hline Wo & 1.6 & 1.5 & 2.0 & & Almandine & 72.3 & 70.8 & 70.4 & \\
\hline En & 35.1 & 36.6 & 26.2 & & Spessartine & 4.6 & 3.4 & 4.5 & \\
\hline Fs & 63.4 & 61.9 & 71.8 & & Grossular & 21.1 & 24.0 & 23.8 & \\
\hline Plagioc & 1 & 2 & 3 & 4 & & & & & \\
\hline $\mathrm{SiO} 2$ & 57.32 & 61.57 & 58.57 & 57.68 & & & & & \\
\hline $\mathrm{A} 12 \mathrm{O} 3$ & 26.94 & 24.34 & 26.05 & 26.75 & & & & & \\
\hline FeOtot & 0.06 & 0.18 & 0.06 & 0.08 & & & & & \\
\hline $\mathrm{CaO}$ & 9.29 & 6.08 & 8.05 & 8.72 & & & & & \\
\hline $\mathrm{Na} 2 \mathrm{O}$ & 6.09 & 7.74 & 6.92 & 6.53 & & & & & \\
\hline $\mathrm{K} 2 \mathrm{O}$ & 0.11 & 0.11 & 0.10 & 0.18 & & & & & \\
\hline $\mathrm{SrO}$ & $<0.11$ & $<0.11$ & $<0.11$ & $<0.11$ & & & & & \\
\hline Total & 99.87 & 100.11 & 99.82 & 100.02 & & & & & \\
\hline
\end{tabular}

Table 2 (continued)

Numbers of ions on the basis of $32(\mathrm{O})$ 

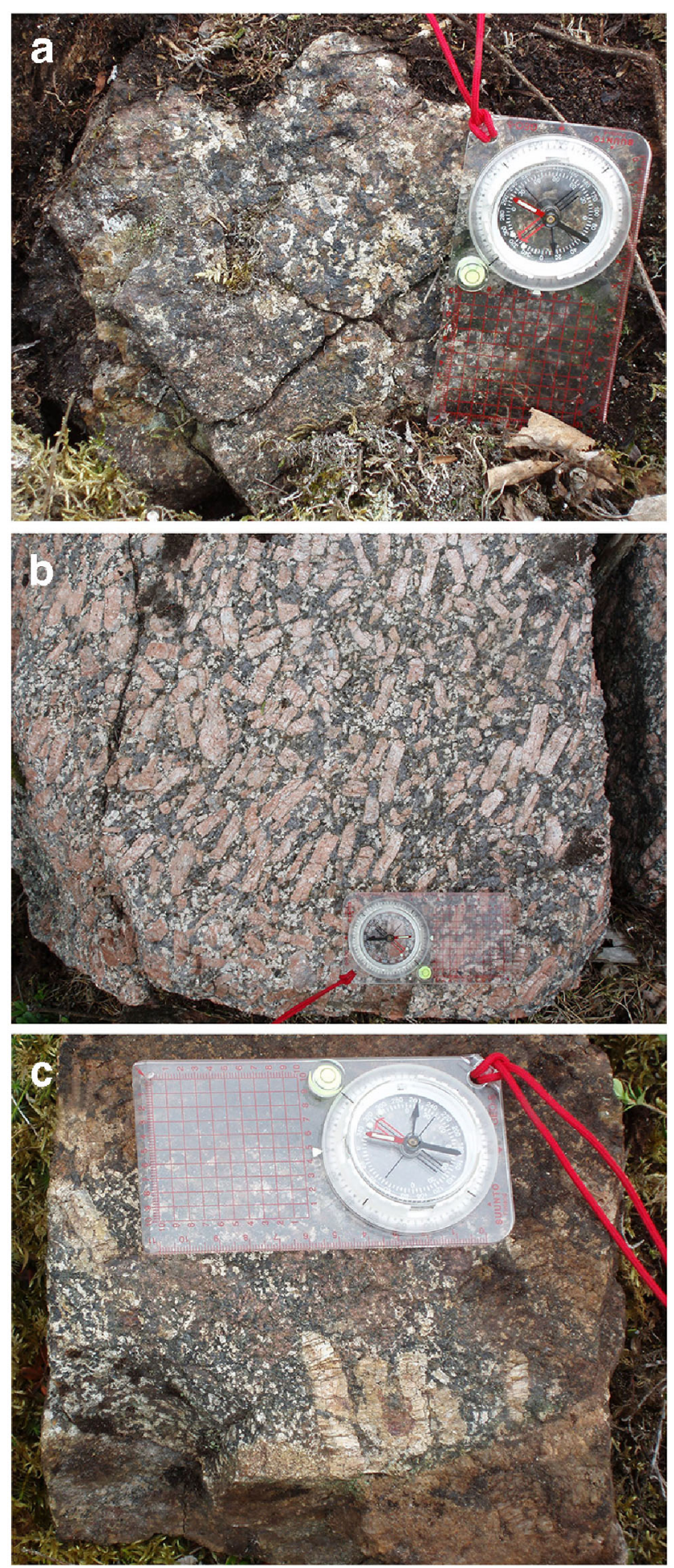

Fig. 2 a The main deposit garnet-bearing fayalite ferrodiorite, observation site TAH\$-2008-18 (UTM, $X=6965.060, Y=484.835$ ). b Megacrystic granite, observation site TAH\$-2009-28 (UTM, $X=$ 6964.520, $Y=485.375)$. c Potassium feldspar phenocrysts in the main deposit ferrodiorite, observation site TAH\$-2008-18. The length of the compass is $12 \mathrm{~cm}$ abundant in all samples. Prismatic apatite grains (up to $1 \mathrm{~mm}$ long) are associated with aggregates of mafic silicates (Fig. 3g). Minor amounts of grunerite, clinoferrosilite, and secondary chlorite and stilpnomelane were identified with electron microprobe analyses (Appendix I). Grunerite is present as a fine-grained, flaky alteration product after fayalite, together with ferrohedenbergite, clinoferrosilite, and Fe-oxides. Small, pale grain aggregates with glassy surfaces in contact with fayalite (Fig. 3h) and as exsolution lamellae in clinopyroxene are probably clinoferrosilite. When in contact with potassium feldspar, large fayalite grains have reaction rims of fine-grained fayalite and feldspar (Fig. 3e).

The main carriers of $\mathrm{Sc}$ in the ferrodiorites are amphibole (103-2088 ppm $\left.\mathrm{Sc}_{2} \mathrm{O}_{3}, n=27\right)$, clinopyroxene (818$1736 \mathrm{ppm}, n=29)$, and apatite (1062 and $1133 \mathrm{ppm}, n=2)$ (Appendix I). Zircon contains, on average, 187 ppm $\mathrm{Sc}_{2} \mathrm{O}_{3}$ and up to $0.46 \mathrm{wt} \% \mathrm{P}_{2} \mathrm{O}_{5}(n=13)$, and shows strong yellow fluorescence. Lesser amounts of $\mathrm{Sc}_{2} \mathrm{O}_{3}$ is present in garnet (44-343 ppm, $n=6$ ), clinoferrosilite (0-199 ppm, $n=13$ ), and plagioclase $(22-175 \mathrm{ppm}, n=18)$.

\section{Heterogeneous diorites}

The area to south and south-east of the main deposit consists of a heterogeneous assemblage of dioritic and monzodioritic rocks (Fig. 1). In the eastern parts of the intrusion, the metadioritic rocks are rich in amphibole and garnet (locally $>50$ vol. $\%$ ). Other minerals include orthopyroxene, biotite, quartz, zircon, and apatite. To the south the rocks are more siliceous, recrystallized, and consertal. The main mafic constituents are orthopyroxene $\left(\mathrm{En}_{35}\right)$ (Table 2) and amphibole, while ferroaugitic-salitic clinopyroxene, biotite, and apatite are present in accessory amounts. The $\mathrm{Sc}_{2} \mathrm{O}_{3}$ concentration in amphiboles, clinopyroxenes, and apatites from pyroxene diorites are 483-855 ppm, $(n=2)$; 606-976 ppm, $(n=10)$; and max. $1036 \mathrm{ppm},(n=2)$, respectively. $\mathrm{Sc}_{2} \mathrm{O}_{3}$ concentration of orthopyroxenes is below detection limit (157 ppm).

\section{Megacrystic granite}

The granite body surrounding the mafic intrusion has oriented, euhedral feldspar laths (length 1-8 cm, Fig. 2b). The feldspar megacrysts consist of a single potassium feldspar crystal (microcline), sometimes surrounded by a thin rim of granular quartz and plagioclase. Individual plagioclase grains $(1-3 \mathrm{~mm})$ are bent. Biotite laths are 

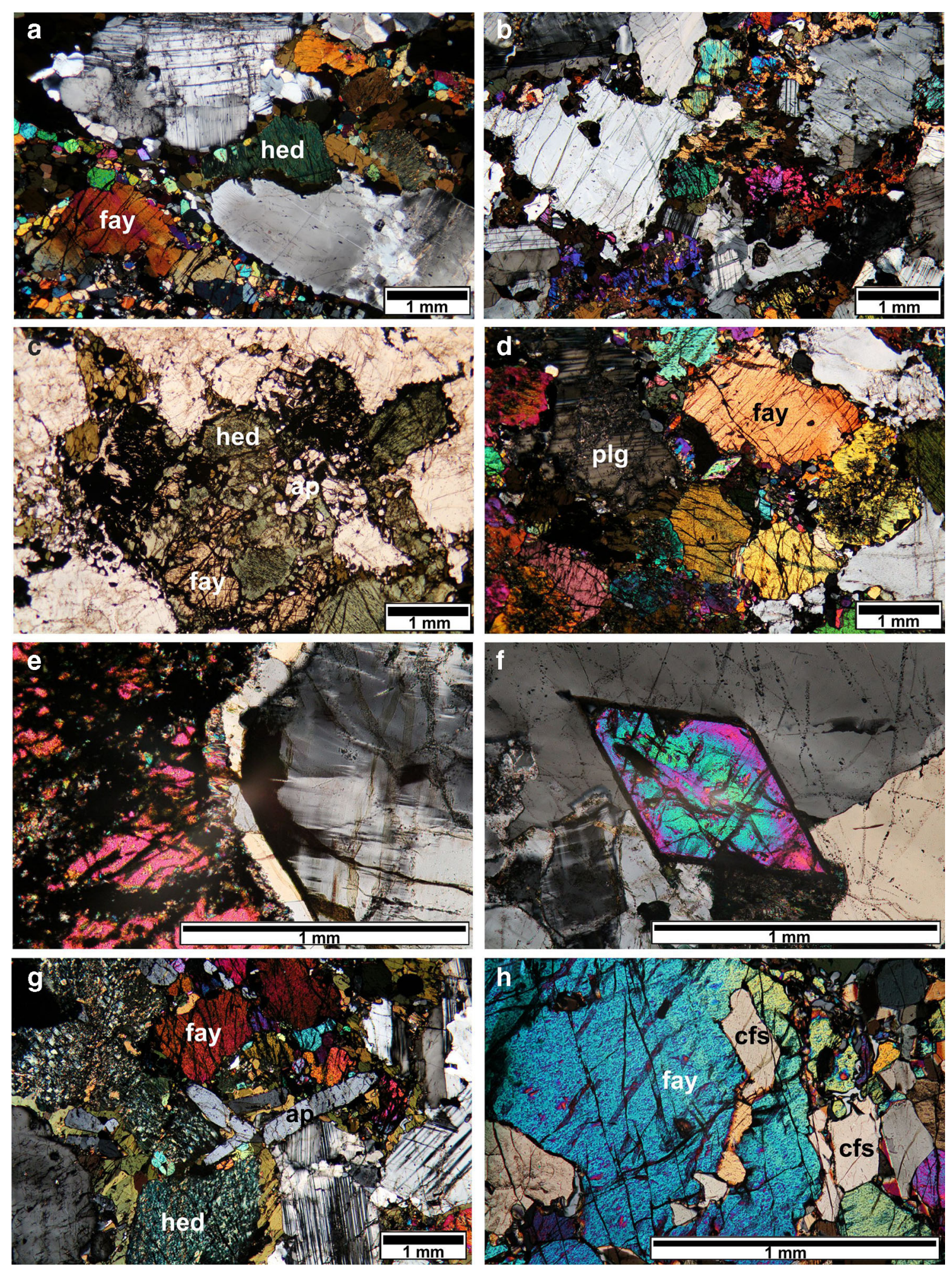

Fig. 3 a Recrystallization texture with corona amphibole in ferrodiorite $(\mathrm{R} 1 / 209 \mathrm{~m})$, crossed polars. b Ilmenite-rich ferromonzodiorite (R1/ $15.20 \mathrm{~m}$ ), crossed polars. c Aggregate of mafic minerals in ferrodiorite (R2/96 m), plane polarized light. d Euhedral zircon (center) in fayalite pyroxenite cumulate (R331/6.80 m), crossed polars. e Double reaction rim between fayalite and potassium feldspar in ferrodiorite $(\mathrm{R} 1 / 73 \mathrm{~m})$,

crossed polars. f Zoned, euhedral zircon in ferrodiorite (R1/112.3 m), crossed polars. g Apatite prisms in ferrodiorite (R331/12.20 m), crossed polars. h Fayalite and clinoferrosilite in ferrodiorite (R3/59.65 m), crossed polars. hed hedenbergite, fay fayalite, ap apatite, plg plagioclase, $c f s$ clinoferrosilite 
also oriented and partly chloritized. Minor amounts of orthopyroxene, altered amphibole, opaque minerals, and zircon are present. Orthopyroxene is the also the main mafic silicate in the granitoid dikes that cut through the main deposit. These dikes have a mortar texture resembling the surrounding granite. Some of the granitoid dikes from drill core R1 are sheared and altered and biotite is the only major mafic constituent. $\mathrm{Sc}_{2} \mathrm{O}_{3}$ concentrations in amphiboles and apatites in the megacrystic granite and pyroxene granitoid dike are $402-565 \mathrm{ppm}(n=6)$ and 1069 ppm $(n=1)$, respectively.

\section{Geochemistry}

\section{Ferrodiorites and leucoferrodiorites of the Kiviniemi main deposit}

Geochemically, the Kiviniemi mafic body is metaluminous (Fig. 4a) and tholeiitic (Fig. 4b) and notably enriched in iron relative to magnesium (Table 1 and Appendix II). The main deposit ferrodiorites $\left(\mathrm{SiO}_{2}\right.$ values of 35.3-50.6 wt $\%, 44.8 \pm 3.4 \mathrm{wt} \%$ on average, $n=31$ ) have $\mathrm{FeO}_{\text {tot }}$ values of $11.7-33 \mathrm{wt} \%(23.1 \pm 3.7 \mathrm{wt} \%$ on average) and magnesium number (Mg\#) of 5-10.9 (7.5 \pm 1.55 on average), clustering near the $\mathrm{F}$ corner of the AFM ternary diagram (Fig. 4b). The leucoferrodiorites $\left(\mathrm{SiO}_{2}\right.$ ca. $\left.51 \mathrm{wt} \%, n=8\right)$ have maximum $\mathrm{FeO}_{\text {tot }}$ of $25 \mathrm{wt} \%$ (Fig. 5) and average $\mathrm{Mg \#}$ of 11 . With respect to $\mathrm{TiO}_{2}, \mathrm{P}_{2} \mathrm{O}_{5}$ (Fig. 5), and $\mathrm{MnO}$ concentrations (1-3 wt $\%$, $0.4-1.5 \mathrm{wt} \%$, and $0.4-1.8 \mathrm{wt} \%$, respectively, for all of the ferrodiorites), the differences are less pronounced.

The ferrodiorites are characterized by elevated concentrations of Sc, Zr, Y, Hf, and Ba and comparatively low compatible element concentrations $(\mathrm{Ni}$ and $\mathrm{Cr}$ mostly below detection limit of $20 \mathrm{ppm}, \mathrm{Cu} 20-60 \mathrm{ppm}, \mathrm{V}<$ $100 \mathrm{ppm})$. The range of concentrations of $\mathrm{Sc}$ is 50 $281 \mathrm{ppm}(n=42)$ and $\mathrm{Zr} 275-5600 \mathrm{ppm}$. The $\mathrm{Zr}$ concentrations are high throughout the intrusion, while the highest whole-rock Sc concentrations are in the main deposit ferrodiorites, including the fayalite pyroxenites, which are the most enriched in mafic Sc-bearing minerals. The concentration of $\mathrm{Y}$ is $58-189 \mathrm{ppm}$, that of $\mathrm{Hf} 7-$ $115 \mathrm{ppm}$, and the ferrodiorites also contain a relatively high amount of $\mathrm{Zn}$ (291-780 ppm), in contrast to the otherwise low compatible element concentrations. Ba abundances are variable but high in all analyzed ferrodiorites (160-3586 ppm), while Sr shows only moderate variation, with an average concentration of $280 \mathrm{ppm}$. The amount of rare earth elements (REE) in all
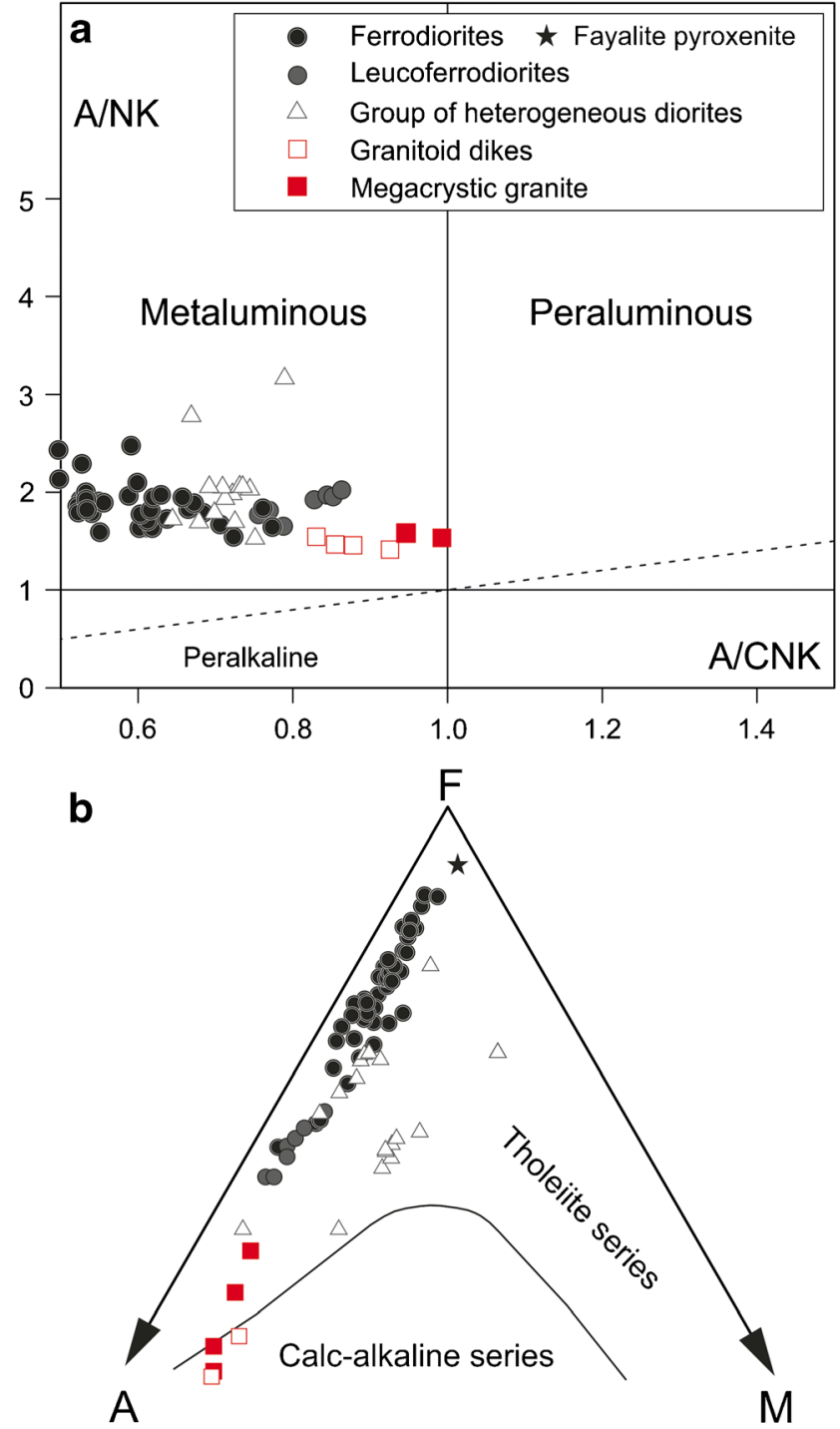

Fig. 4 a A/NK vs. A/CNK plot after Shand (1943), showing the samples with $\mathrm{A} / \mathrm{CNK}<0.5$. b AFM ternary diagram after Irvine and Baragar (1971)

ferrodiorites is 336-974 ppm (558 ppm on average). Eu anomalies are mostly negative with an average $\mathrm{Eu} / \mathrm{Eu}^{*}$ of 0.7. The chondrite-normalized REE diagram shows rather similar, gently sloping patterns for all the mafic rock units of the Kiviniemi intrusion (Fig. 6). $\mathrm{La} / \mathrm{Yb}_{\mathrm{N}}$ for the ferrodiorites is between 2 and 5 .

\section{Transitional group of heterogeneous diorites}

The diorites outside the main deposit (cf. Fig. 1) have Mg\# from 13-17 (metamorphic monzodiorites) to 30-34 (pyroxene diorites). The concentrations of $\mathrm{TiO}_{2}$ and $\mathrm{V}$ (max. $4 \mathrm{wt} \%$ and $230 \mathrm{ppm}$, respectively) are higher than 
Fig. 5 Binary plots of major elements versus $\mathrm{SiO}_{2}$ (weight percent). Skaergaard values (Upper zone and Sandwich Horizon) after McBirney (1998), Bolangir values (ferrodiorite suite) after Bhattacharya et al. (1998)
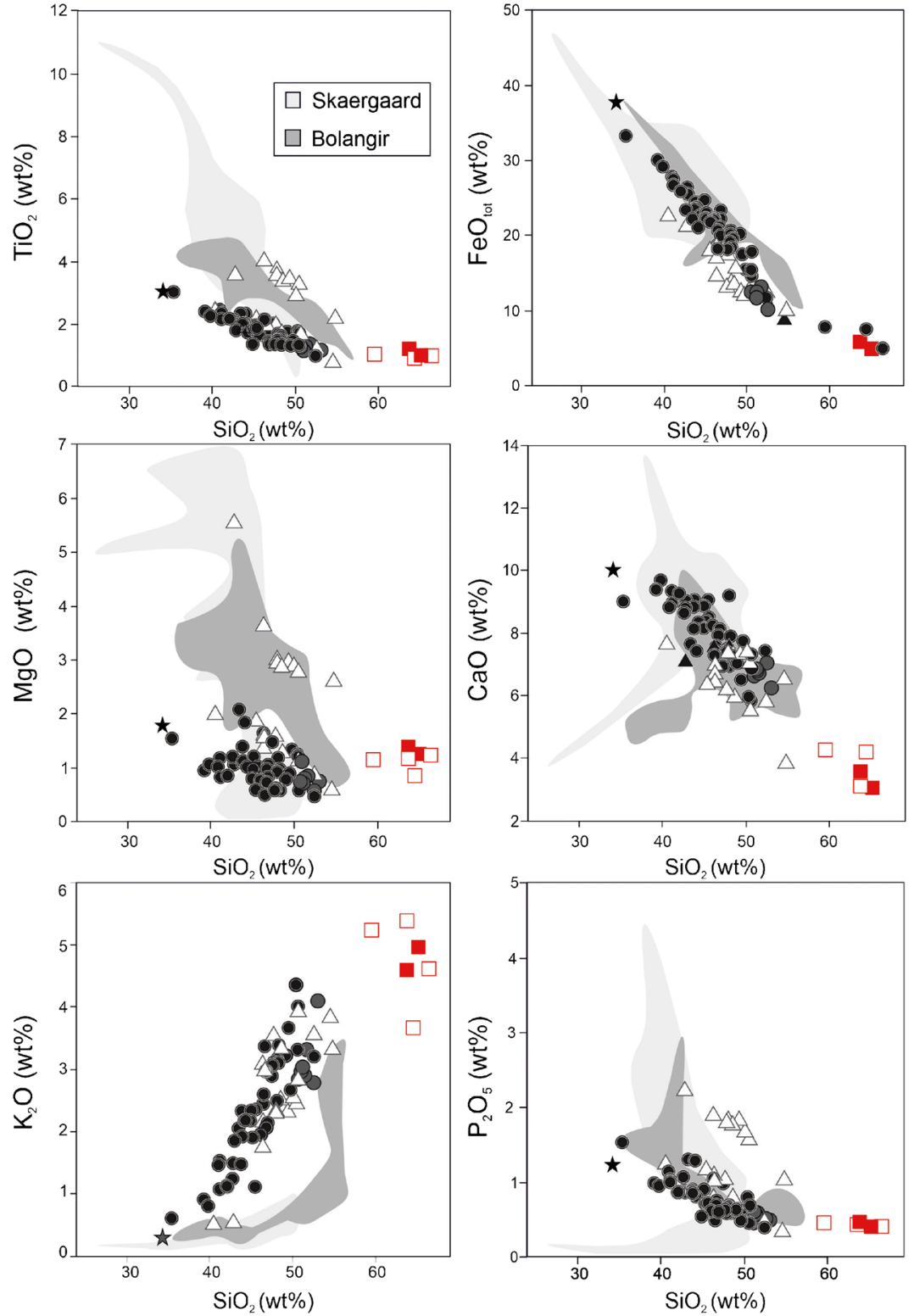

$\star$ Fayalite pyroxenite - Ferrodiorites O Leucoferrodiorites

$\triangle$ Group of heterogeneous diorites $\square$ Granitoid dikes $\square$ Megacrystic granite in the main deposit ferrodiorites and leucoferrodiorites. Among the compatible elements, $\mathrm{Ni}, \mathrm{Cr}$, and $\mathrm{Cu}$ show values below detection limits or just above it. Higher $\mathrm{P}_{2} \mathrm{O}_{5}(0.8-2.2 \mathrm{wt} \%)$ correlates with abundant apatite. Monzodiorites near the contact with the main deposit rocks show similar values of $\mathrm{Zr}$ (over $1000 \mathrm{ppm}$ ) and $\mathrm{Y}(\sim 100-200 \mathrm{ppm})$, but the Sc concentration remains low throughout the group, with average value at $45 \mathrm{ppm}$ $(n=18)$.

\section{Megacrystic granite and granitoid dikes}

The Kiviniemi megacrystic granite is transitional between the C- and A-type granitoids (cf. Nironen et al. 2000 and references therein). Relatively low $\mathrm{SiO}_{2}$ (63.7-65.1 wt\%) and $\mathrm{Rb} / \mathrm{Sr}$ ratio (0.7) as well as higher $\mathrm{FeO}$ and $\mathrm{CaO}$ distinguish it from the A-type granites and the classic rapakivi granites of southeastern Finland. The average $\mathrm{Mg} \#$ of the megacrystic granite is $27, \mathrm{TiO}_{2}$ is between 1 and $1.5 \mathrm{wt} \%$, 


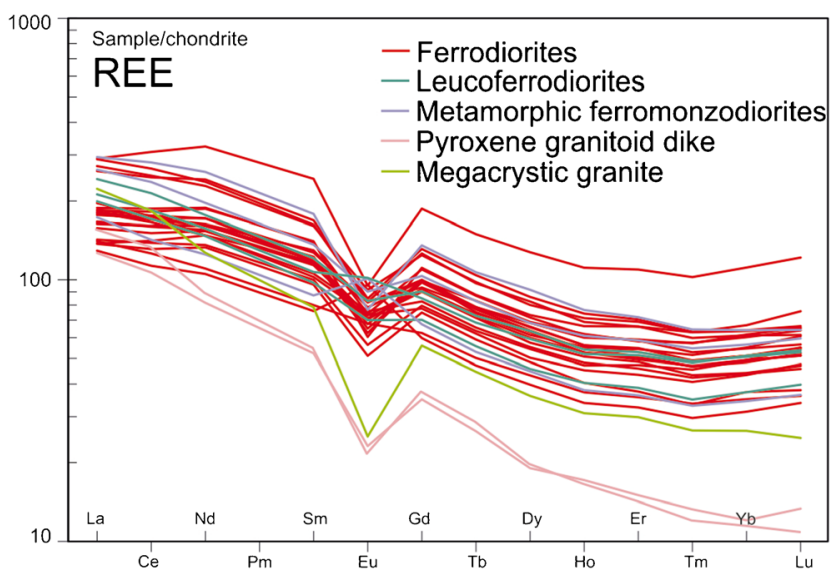

Fig. 6 Chondrite-normalized REE-pattern of the rock types analyzed from the Kiviniemi mafic intrusion and the surrounding granite. Normalizing values after Boynton (1984)

and $\mathrm{P}_{2} \mathrm{O}_{5}$ at $0.37-0.6 \mathrm{wt} \%(n=2)$. The megacrystic granite and an associated granitoid dike show elevated $\mathrm{Zr}$ (379$771 \mathrm{ppm})$ but low Sc (14-16 ppm). The REE pattern has similarities to the mafic rock units (Fig. 6). The LREE are less enriched than in the CFGC granitoid plutons in general (La/ $\mathrm{Yb}_{\mathrm{N}}$ 11-12; Nironen et al. 2000; Elliott 2003).

\section{Zircon U-Pb chronology and whole-rock Sm-Nd isotopes}

The zircon grains in the ferrodiorite (A2024) show typical magmatic textures with oscillatory zoning and being transparent, fresh, and bright. During sample processing, zircon grains were crushed to $\sim 200 \mu \mathrm{m}$ pieces, and thus represent fragments of larger igneous crystals. Three zircon fractions were measured using the ID-TIMS method: one fraction without pre-treating (density over $4.2 \mathrm{~g} / \mathrm{cm}^{3}$ ), an air-abraded fraction, and the third fraction was pre-treated with chemical abrasion (cf. Mattinson 2005). The data acquired are presented in Appendix III. The fractions are concordant within error limits $(2 \sigma)$ and imply a concordia age of $1857 \pm 2 \mathrm{Ma}$. This is considered to be the crystallization age of the Kiviniemi ferrodiorite (Fig. 7a).

Zircons from the megacrystic granite (A2146) are euhedral, 100-200- $\mu \mathrm{m}$-long, and oscillatory zoned with moderately corroded outer zones. The measurements were performed using the LA-MC-ICP-MS method (Appendix III). A total of 31 analyzed spots yield a concordia age of $1860 \pm 7 \mathrm{Ma}$ (Fig. 7b). This is regarded as a good approximation of the crystallization age of the megacrystic granite.

$\mathrm{Sm}-\mathrm{Nd}$ isotopic data measured for the Kiviniemi ferrodiorite and megacrystic granite are presented in
Appendix III. The calculated initial $\varepsilon N d$ for the ferrodiorite and the megacrystic granite are $+0.1(t=1857)$ and $-2.5(t=$ $1860)$, respectively. The corresponding depleted mantle $\mathrm{Nd}$ model ages (DePaolo 1981) are $2264 \mathrm{Ma}$ (ferrodiorite) and $2468 \mathrm{Ma}$ (megacrystic granite). Figure 8 shows the initial $\varepsilon \mathrm{Nd}$ values of the Kiviniemi ferrodiorite and megacrystic granite in comparison to the $\mathrm{Nd}$ isotope composition of the Svecofennian crust and the evolution paths of the Paleoproterozoic and Archaean crustal domains of the Fennoscandian shield.

\section{Discussion}

\section{Age and Nd isotopic patterns of the Kiviniemi intrusion and other post-kinematic bimodal magmatic associations of the CFGC}

The Kiviniemi ferrodiorite $(1857 \pm 2 \mathrm{Ma})$ and the surrounding granite $(1860 \pm 7 \mathrm{Ma})$ can be considered coeval within analytical error limits. The overlapping ages of granitoids and associated mafic rocks are a common phenomenon among the Svecofennian post-kinematic intrusions (Rämö et al. 2001) and the post-kinematic mafic intrusions, which often show evidence for magma mingling, are commonly considered to be co-genetic but not co-magmatic with their granitoid associates (Nironen et al. 2000). At Kiviniemi, this is evident in geochemistry as well as in the textural relationships of the rocks, which display mingling. The pyroxene diorites in the southern parts of the intrusion have a similar $\mathrm{Mg} / \mathrm{Fe}$ ratio $(\mathrm{Mg} \#$ $\sim 30$ ) and also resemble mineralogically the surrounding granite: in both rock types, the proportion of mafic minerals is lower and orthopyroxene is present. In addition, potassium feldspar xenocrysts are found locally throughout the mafic body (see Fig. 2c). The bimodal association of the CFGC post-kinematic rocks resembles that of the Finnish anorogenic rapakivi granites and related mafic intrusions (Heinonen et al. 2010).

The CFGC post-kinematic granitoids have $\varepsilon \mathrm{Nd}$ (at $1875 \mathrm{Ma})$ between +0.6 and -1.1 and the post-kinematic mafic rocks tend to have $\varepsilon \mathrm{Nd}$ values similar to the associated granitoid plutons ( +0.6 to -0.7 ; Rämö et al. 2001). The $\varepsilon \mathrm{Nd}$ value of the post-kinematic Type 3 pyroxene granites analyzed near Kiviniemi by Rämö et al. (2001) is $-0.7(t=$ $1875 \mathrm{Ma}$, while 1.93-1.91 Ga felsic gneisses have an average $\varepsilon N d$ of +2.2 (Lahtinen and Huhma 1997). In this context, the $\varepsilon \mathrm{Nd}+0.1$ of Kiviniemi ferrodiorite is similar to that of the post-kinematic mafic magmatism while the $\varepsilon \mathrm{Nd}$ of the megacrystic granite is slightly, yet probably significantly, 


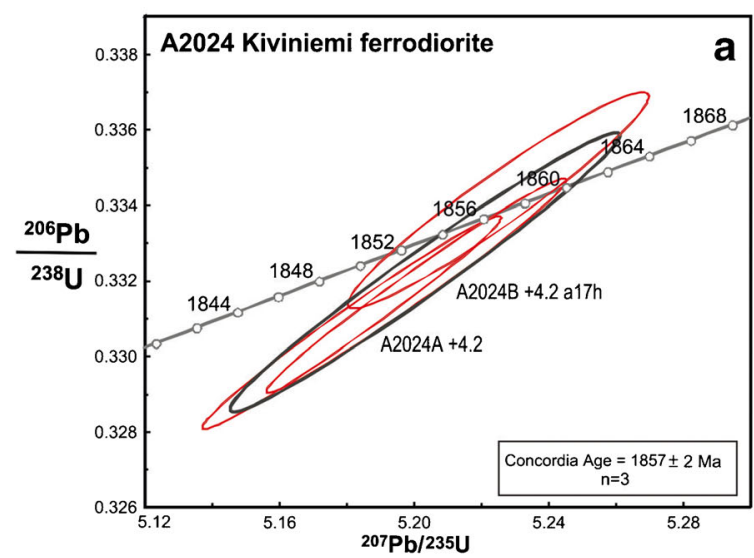

Fig. 7 Concordia diagrams showing the results of Kiviniemi U-Pb zircon age determinations from a ferrodiorite (multi grain ID-TIMS), b

more negative $(-2.5)$, indicating minor involvement of older (Archaean) crustal material either in the source or as a contaminant (Fig. 8).

The Kiviniemi ferrodiorite and the surrounding megacrystic granite belongs to the youngest phase of the

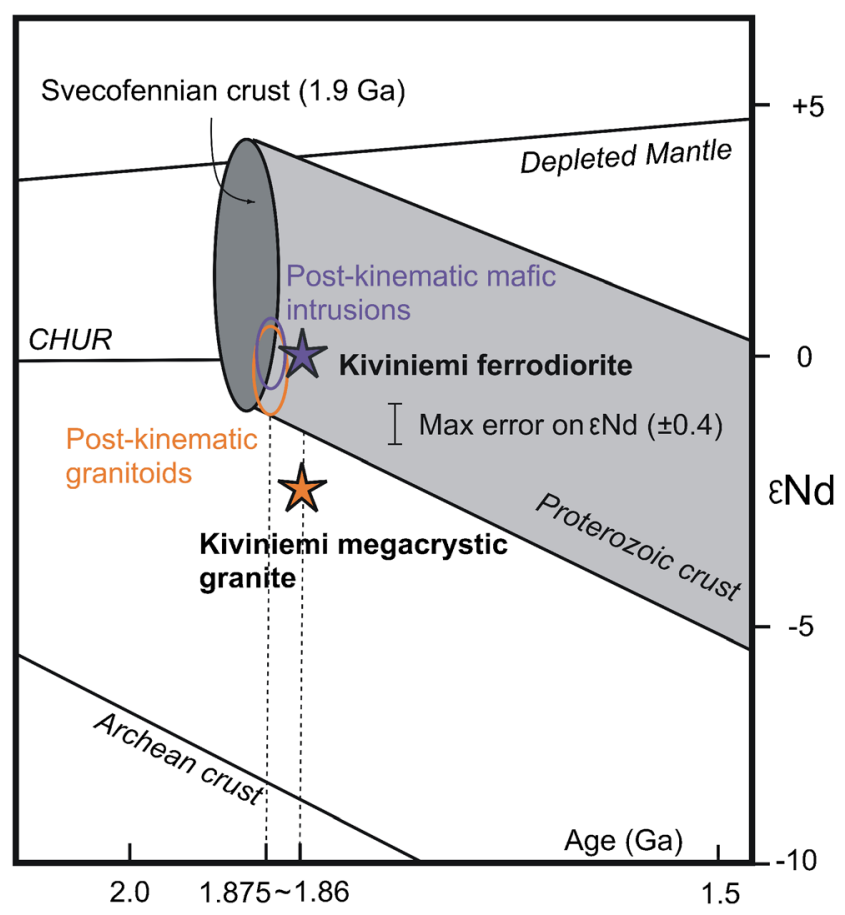

Fig. $8 \varepsilon N d$ vs. age diagram showing the initial $\varepsilon N d$ values of the Kiviniemi ferrodiorite and the surrounding megacrystic granite with respect to evolutionary trends of Proterozoic (mainly Svecofennian) and Archean crust. External error expressed as $2 \sigma(\varepsilon N d \pm 0.4)$. Reference data from Huhma (1986), Patchett and Kouvo (1986), and Rämö et al. (1996). Value field for post-kinematic mafic intrusions and granitoids from Rämö et al. (2001)

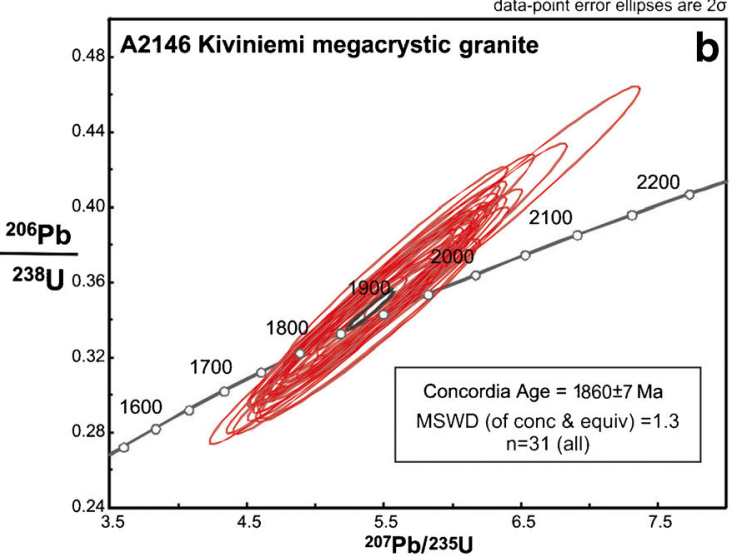

megacrystic granite (single grain LA-MC-ICP-MS). The data-point error limits are $2 \sigma$

CFGC magmatism. According to Nironen et al. (2000), the oldest post-kinematic intrusions $(\sim 1.88 \mathrm{Ga})$ are located in the NE parts of the CFGC and the young ages $(1.87 \mathrm{Ga})$ more comparable to Kiviniemi are mostly found in the west. Obviously, Kiviniemi does not fit this scheme but is comparable to the $<1.86 \mathrm{Ga}$ intrusions in the northwestern parts of the CFGC (cf. Vaasjoki and Sakko 1988; Kontinen et al. 2013).

According to the current conceptual understanding, orogenic thickening of the Svecofennian crust was followed by post-orogenic gravitational collapse and resultant pressure release and concomitant mafic underplating, inducing melting of rock domains in the lower crust (e.g., Nironen 1997). The post-kinematic granitoid plutons have a similar chemical composition to that at Kiviniemi (cf. Elliott et al. 1998) and the associated mafic rocks probably formed by melting of mafic granulitic lower crust (residue of preceding synkinematic magmatism) with heat and material input from mantlederived tholeiitic melts (Nironen et al. 2000; Rämö et al. 2001; Elliott 2003). Cumulate textures (Rämö 1986) and megacyclic layering (Nironen et al. 2000 and references therein) are occasionally well preserved in the mafic intrusions. The model outlined by Elliott (2003) - a 30\% partial melt from a mixture of mafic granulite plus tholeiitic mantlederived magma - is probably also plausible for Kiviniemi, given the geochemical similarities between the two rock types.

\section{Geochemical constraints on the origin of Kiviniemi ferrodiorites}

The Kiviniemi mafic intrusion and the other postkinematic mafic rocks of the CFGC (e.g., Nironen et al. 
2000) share similar evolved characteristics: high Fe, Ti, and $\mathrm{P}$ and low $\mathrm{Ni}$ and $\mathrm{Cr}$. A common source is suggested for these rocks, with the Kiviniemi intrusion being exceptional in regard to the extremely elevated Sc (max. $281 \mathrm{ppm}), \mathrm{Zr}$ (max. $5600 \mathrm{ppm}$ ), and Y (max. $189 \mathrm{ppm}$ ). The trace element enrichment history in Kiviniemi is multiform, with some LIL or HFS elements being clearly enriched ( $\mathrm{Zr}, \mathrm{Y}, \mathrm{Hf}, \mathrm{Sc}, \mathrm{K}, \mathrm{Ba})$ or moderately depleted (Th, U, Sr). This indicates a complex magmatic evolution and is probably linked to the formation of stable fluoride and phosphate complexes (Gramaccioli et al. 2000). The variations in the Kiviniemi trace element concentrations can in part be explained by the internal heterogeneity of the medium- to coarse-grained ferrodiorite. Whether this heterogeneity is a primary feature related to magma movement, layering, or mingling remains to be determined as subsequent modification of the textures and structures have obscured the original textural traits.

Mafic magmatism with a weak to strong shoshonitic fingerprint is also present in the Archaean domain of eastern Finland (Mikkola et al. 2014) and in the southern part of the Svecofennian domain (Eklund et al. 1998; Rutanen et al. 2011). These rocks display a clear signature of either subduction-related or mantle metasomatism-induced source with high LILE and low HFSE. The mafic magmatism of central Finland, temporally as well as geographically located between these two domains, represents an entirely different petrogenetic process which probably involved mafic intraand underplating of the thickened crust in a transtensional or extensional tectonic setting after the main collisional event of the Svecofennian orogeny (e.g., Nironen 1997). The differences concerning the variation in the HFSE and LILE enrichment among the CFGC granitoids have provoked discussion of small-scale heterogeneities in the subcontinental mantle. Lahtinen and Huhma (1997) suggested an enriched mantle source for the CFGC alkaline rocks with high $\mathrm{Ba} / \mathrm{La}$ ratio. The $\mathrm{Sm} / \mathrm{Nd}$ ratio near 0.24 is seen as indicative of enriched mantle sources in general (Murphy and Dostal 2007) and crustal contamination as a mechanism for generating shoshonitic magmatism is considered improbable because of low LILE and REE contents of probable contaminants (cf. Eklund et al. 1998).

The late- to post-tectonic appinitic rocks of northern Finland (Mutanen 2011) appear to follow the same tholeiitic fractionation path as the Fe-Ti-P-rich intrusions of central Finland, sharing obvious similarities in geochemical character and a bimodal association with syenites. $\mathrm{Zr}$ is strongly enriched into the latest differentiates, while $\mathrm{Ni}$ and $\mathrm{Cr}$ are low. Due to high REE, $\mathrm{Zr}, \mathrm{K}, \mathrm{Rb}, \mathrm{P}, \mathrm{Th}$, and $\mathrm{U}$, a selective diffusion in the lower crust is proposed for the appinites (Mutanen 2011). However, geochemical differences relative to the Kiviniemi intrusion are rather substantial - the appinites are much more enriched in V, $\mathrm{Sr}, \mathrm{Cl}, \mathrm{Th}$, and $\mathrm{U}$, and lack the extreme iron enrichment and high Sc and Y.

In search of a wider perspective, the ferrodiorites of Kiviniemi are here compared to the Upper Zone and the Sandwich Horizon of the Skaergaard layered intrusion, eastern Greenland (Wager and Deer 1939; Brooks 1969; Haskin and Haskin 1968; McBirney 1995, 1998, 2002) and to the ferrodiorite suite of the Bolangir Anorthosite Complex, India (Raith et al. 1997; Bhattacharya et al. 1998). In addition to iron enrichment via differentiation and fractionation, the ferrodiorites in Bolangir also show high concentrations of various HFSE and REE. In Skaergaard, the concentrations of incompatible elements increase concomitantly with the iron enrichment associated with residual liquid evolution. The variation of compositions in the Skaergaard and Bolangir ferrodiorites is wider than in Kiviniemi (see Fig. 5) but they share a similar trend. The concentration of $\mathrm{K}_{2} \mathrm{O}$ in Kiviniemi is higher than in Skaergaard and Bolangir. This may, in part, be due to the incorporated potassium feldspar xenocrysts from the wall rock granite.

The extremely high HFSE and REE contents in the Bolangir ferrodiorites have been attributed to selective assimilation of local felsic crust by a residual ferrodioritic liquid (e.g., Raith et al. 1997). Assimilation of accessory zircon, monazite, and apatite would add REE and HFSE, sufficient to cause prominent concentrations with even small volumes of assimilated material. The concentrations of $\mathrm{Th}, \mathrm{Y}, \mathrm{Nb}$, and trivalent REE, probably caused by selective assimilation in the Bolangir ferrodiorite suite (Raith et al. 1997; Bhattacharya et al. 1998), are significantly higher (especially for Th) than in Kiviniemi, which does not support the selective assimilation theory. The use of the trace element composition of zircon as a provenance/origin indicator is widely debated and problematic, which appears to be true for Kiviniemi as well. For instance, the $\mathrm{Zr} / \mathrm{Hf}$ ratio of Kiviniemi zircons is similar to that in kimberlite and carbonatite rocks while the $\mathrm{P}_{2} \mathrm{O}_{5}$ content of $0-0.46 \mathrm{wt} \%$ would indicate a granitic source (cf. Hoskin and Ireland 2000; Belousova et al. 2002). However, the high Sc content in zircon in mafic rocks (86-230 ppm, Heaman et al. 1990) appears to reflect the overall higher Sc content of mafic magmas. In the ferrodiorites of Kiviniemi, Sc in zircon is between 50 and $310 \mathrm{ppm}$, which is compatible with the Kiviniemi magmas having been enriched in $\mathrm{Sc}$ and $\mathrm{Zr}$ prior to crystallization.

Stabilization of Fe-Ti-oxides is one of the main controlling factors of the tholeiitic Fe-enrichment trend (e.g., 
Naslund 1983; Toplis and Carroll 1996; Wiebe 1997). Iron-enriched magmas may, however, exhibit non-ideal behavior depending on composition and conditions. High $\mathrm{P}_{2} \mathrm{O}_{5}$ concentration of the crystallizing magma, for example, destabilizes magnetite allowing residual magmas to reach high $\mathrm{FeO}$ content even under oxidizing conditions (Toplis et al. 1994). $\mathrm{P}_{2} \mathrm{O}_{5}$ saturation is controlled by variations in the $\mathrm{SiO}_{2}$ and $\mathrm{CaO}$ concentrations of the evolving magma (Tollari et al. 2006), which in turn has implications for the high Ti and $\mathrm{P}$ associated with Fe-rich evolved liquids. Iron enrichment via redox control is argued to proceed only up to $\sim 22 \%$ of $\mathrm{FeO}$, after which the unmixing of late-stage magmas is considered to be an essential process, as for example in the Skaergaard intrusion (e.g., McBirney and Nakamura 1974). Redox conditions and the existence of primary melt inclusions (cf. Jakobsen et al. 2005) in the Kiviniemi intrusion are not yet established. The moderately enriched phosphorus concentrations (cf. Toplis et al. 1994) and high ilmenite/ magnetite ratio are consistent with the moderate iron enrichment during crystallization. However, the fact that the extreme $\mathrm{FeO}$ concentrations (over $22 \mathrm{wt} \%$; Toplis and Carroll 1996; Thy et al. 2006; Veksler et al. 2008; Veksler 2009) are observed only in alkali-poor samples suggests that liquid immiscibility may have occurred, and this should also be investigated in Kiviniemi, especially with respect to partitioning of Sc, Zr, and Y.

\section{Scandium in the Kiviniemi ferrodiorite system}

Sc is usually grouped geochemically with the REE and Y. The ionic radius of $\mathrm{Sc}$ is, however, smaller than that of the lanthanides and $\mathrm{Y}$ and thus the behavior of $\mathrm{Sc}$ in fractionation processes is essentially different (Norman and Haskin 1968). Instead of enrichment in the residual liquid, $\mathrm{Sc}^{3+}$ is easily incorporated into ferromagnesian silicates. Therefore, mafic and ultramafic rocks are typically more enriched in Sc than felsic rocks (Norman and Haskin 1968).

The main carriers of $\mathrm{Sc}$ at Kiviniemi are ferropargasite and ferroedenite (max. $\mathrm{Sc}_{2} \mathrm{O}_{3} 2088 \mathrm{ppm}$ ), (ferro)hedenbergite (max. $\mathrm{Sc}_{2} \mathrm{O}_{3} 1621 \mathrm{ppm}$ ), and fluorapatite $\left(\max . \mathrm{Sc}_{2} \mathrm{O}_{3}\right.$ $1133 \mathrm{ppm})$. It is notable that, also in the surrounding megacrystic granite and granitoid dikes cross-cutting the main deposit, the concentration of $\mathrm{Sc}_{2} \mathrm{O}_{3}$ in amphibole and apatite is high (max. 565 ppm and 1069 ppm, respectively). The differences in the whole-rock Sc concentrations between different rock units thus reflect the amount of Sc-bearing minerals, as is the case also in the Skaergaard intrusion (McBirney 1998). Nevertheless, the Sc concentrations at Kiviniemi (50$281 \mathrm{ppm}$ in whole-rock analyses) are much higher than those

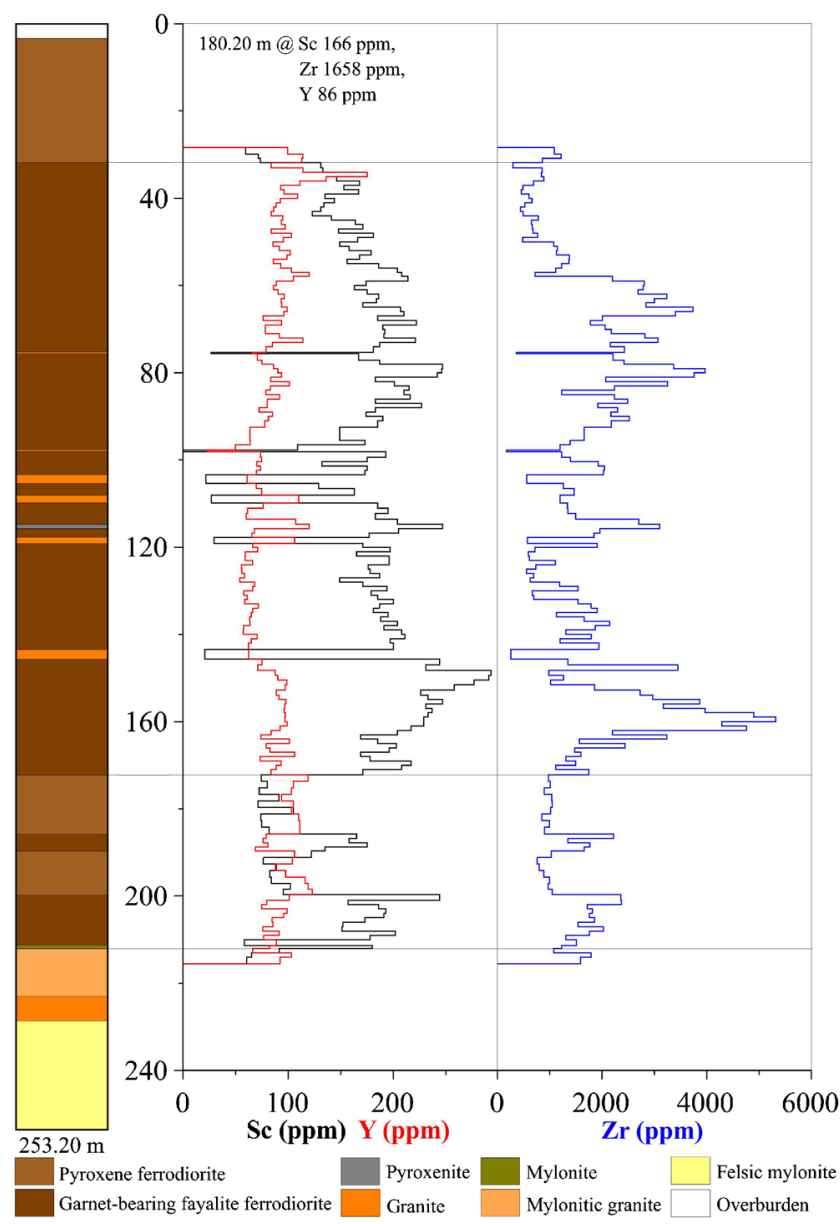

Fig. 9 Rock type column and variations in scandium, yttrium, and zirconium concentrations of the diamond drill hole P433/2010/R1 (R1 in Fig. 10). Modified after Halkoaho and Niskanen (2015)

in Bolangir or Skaergaard. Assimilation of Sc from the surrounding felsic rocks is ruled out by the significantly lower $\mathrm{Sc}$ concentration (typically <20 ppm; Norman and Haskin 1968, in Kiviniemi porphyritic granite $\sim 15 \mathrm{ppm}$ ). Therefore, the origin of Sc in Kiviniemi is most probably magmatic and $\mathrm{Sc}$ was partitioned into ferromagnesian silicates and fluorapatite as these phases were stabilized. Should the magma have contained more Sc, the amount of Sc that could be incorporated in solid solution in clinopyroxene and amphibole would have been exceeded, with resultant stabilization of a separate Sc phase (cf. Foord et al. 1993).

The enrichment of some of the LILE, HFSE, and REE in the Skaergaard intrusion was probably controlled by changing partition coefficients. The abrupt increase in the concentrations of these elements (the change in partition behavior) coincides with the exsolution of a volatile phase, which is connected to an increase in the $\mathrm{F} / \mathrm{Cl}$ ratio of apatites (McBirney 2002). The transition of Sc from being a compatible element to an incompatible one, with consequent enrichment in 

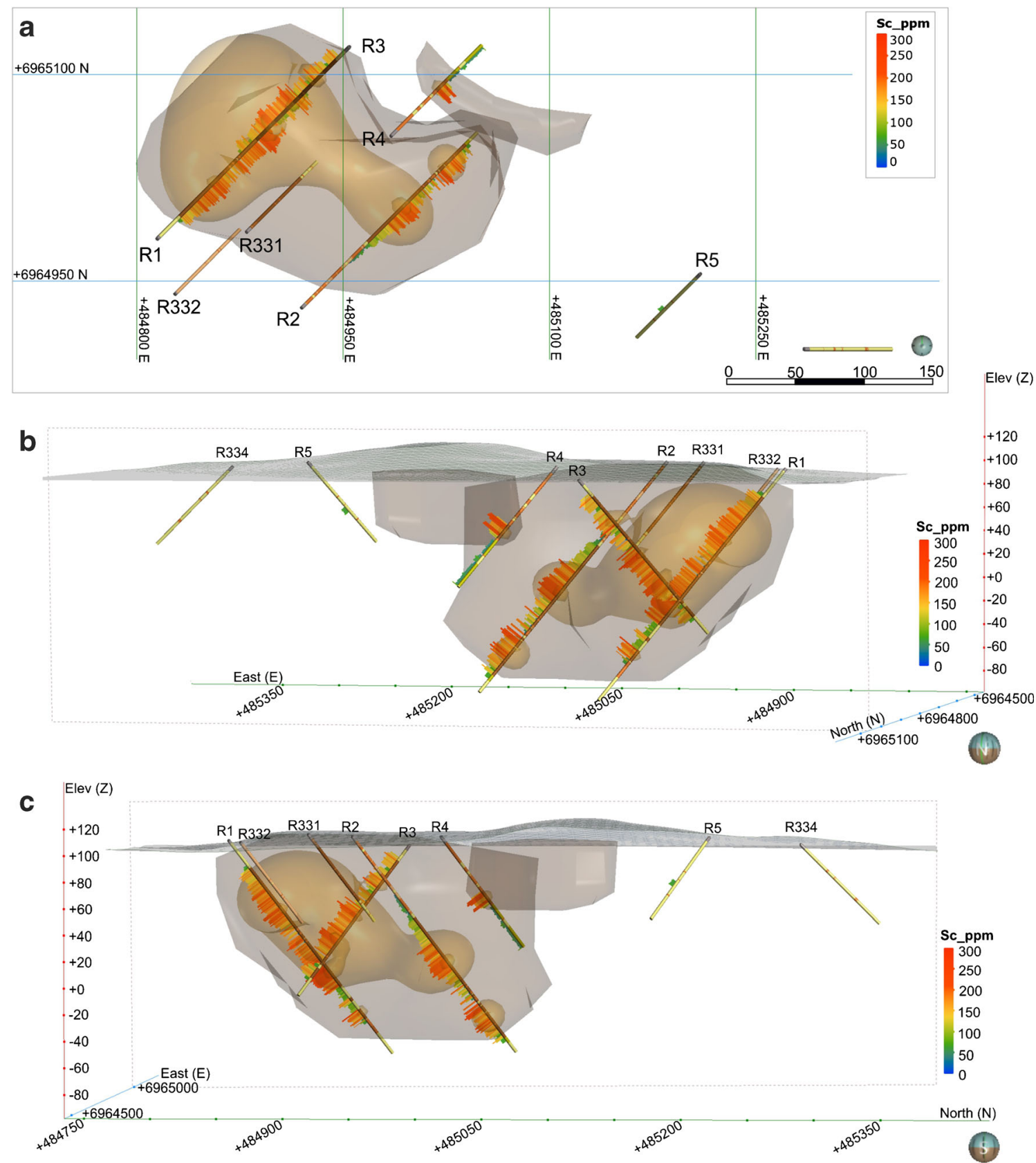

Fig. 10 The 3D model of the Sc-enriched deposit of the Kiviniemi ferrodiorite intrusion. a Plan view of the deposit. The outline of the deposit shown in gray is approximately $200 \times 150 \times 167 \mathrm{~m}$. b The deposit viewed towards south. The digital elevation model (DEM) is used as topographic constraint which is derived from the National Land Survey of Finland's (NLS) Airborne Laser scanning data. Drill holes are shown in yellow together with scandium grade. $\mathbf{c}$ The deposit viewed towards north residual melt, is linked to the $\mathrm{F}$ concentration of the magma and stabilization of fluoride complexes (Gramaccioli et al. 2000). Unlike the REE, Sc, Y, and $\mathrm{Zr}$ have no electrons in the outermost shell. This makes fluorine (and possibly also phosphate) complexes of Sc, Y, and Zr more stable and promotes the enrichment of these elements. After crystallization of the F- and P-bearing phases-fluorapatite in Kiviniemithe activity of $\mathrm{F}$ and $\mathrm{P}$ ligands decreased in the magma, resulting in compatible behavior of $\mathrm{Sc}$ with respect to $\mathrm{Fe}$ Mg-silicates (Gramaccioli et al. 2000; Shchekina and Gramenitskii 2008). This is probably what drove the Sc budget in the Kiviniemi ferrodiorite magma. However, the lack of 
specific Sc-minerals in Kiviniemi also indicates higher crystallization pressure and temperature than in common pegmatite systems, in which most known Sc-minerals are found (e.g., Bernhard 2001; Raade et al. 2002).

The origin of the $\mathrm{Sc}$ enrichment in the Kiviniemi ferrodiorites and leucoferrodiorites is most probably magmatic, given the established F- and/or P-control. Based on earlier studies and the data presented in this paper, a complex evolutionary path for enrichment of Sc is likely, involving interaction between anatectic melts derived from the lower crust and mafic mantle-derived magmas delivering already relatively large amounts of Sc for the primary Kiviniemi magma. However, the possibility of liquid immiscibility should be investigated further with respect to the partitioning of the enriched trace elements, as well as the effects of magma mingling (with special emphasis on F) and the degree of metamorphism during and after crystallization.

The diamond drill hole P433/2010/R1 reflects the homogeneous nature of the deposit, in which only a few thin granite dykes are present, while in the uppermost part and toward the base of the drill hole, there are layers of fine- to middlegrained pyroxene ferrodiorite. Variations in scandium, zirconium, and yttrium abundances in the garnet-bearing fayalite ferrodiorite are quite constant. This is shown in Fig. 9, where at the top of the hole on the southwest side, the fine- to middlegrained pyroxene ferrodiorite occurs and toward the base of the hole, in the northeast, felsic mylonitic rocks dominate (Fig. 9). In the interval $31.80-212.00 \mathrm{~m}(180.20 \mathrm{~m})$, the average content of scandium is $166 \mathrm{~g} / \mathrm{t}$, zirconium $1658 \mathrm{~g} / \mathrm{t}$, and yttrium $86 \mathrm{~g} / \mathrm{t}$ while for the interval $31.80-172.20 \mathrm{~m}$ $(140.40 \mathrm{~m})$, the average content of scandium is $179 \mathrm{~g} / \mathrm{t}$, zirconium $1762 \mathrm{~g} / \mathrm{t}$, and yttrium $83 \mathrm{~g} / \mathrm{t}$ (Halkoaho and Niskanen 2015). GTK completed a 3D model and preliminary "in-situ" resource estimate of $13.4 \mathrm{Mt}$ with an average grade of $162.7 \mathrm{~g} /$ $\mathrm{t}$ scandium, $1726 \mathrm{~g} / \mathrm{t}$ zirconium, and $81 \mathrm{~g} / \mathrm{t}$ yttrium $154 \mathrm{~g} / \mathrm{t}$ on the Kiviniemi deposit in 2016 (Hokka and Halkoaho 2016). A cut-off value of $40 \mathrm{~g} / \mathrm{t} \mathrm{Sc}$ was applied. The estimation was done without consideration of potential economic extraction and, therefore, it is an estimate of conceptual nature and reflects only the potential quantity and grade. Nevertheless, the concentration of Sc in the Kiviniemi deposit is so high, that it will classify Kiviniemi a large Sc-deposit.

In this article, the Seequent Limited Leapfrog Geo software (version 4.4.2) was used to generate the 3D visualization of the Kiviniemi deposit. The fayalite ferrodiorite part of the intrusion forms from two separate bodies which are modeled using data from the surface geological mapping, ground magnetic survey, and core logging data derived from six drill holes (Fig. 10). In Fig. 10, the grade shells are interpolated using polyharmonic Radial Basis Functions (Carr et al. 2001) to create likely concentrations of scandium between the existing scattered data points. The yellow-colored grade shells represents an isosurface interval range of $150-200 \mathrm{~g} / \mathrm{t}$ scandium which is close to the potential range of grade estimated previously in Hokka and Halkoaho (2016).

\section{Conclusions}

1. The Kiviniemi mafic intrusion, located in the northeastern margin of the CFGC, includes a Sc-deposit hosted by garnet-bearing fayalite ferrodiorite and leucoferrodiorite.

2. The intrusion is spatially and temporally associated with small mafic-ultramafic intrusions of the CFGC. Mineralogical and geochemical features (high $\mathrm{Fe}$, Ti and $\mathrm{P}$, elevated $\mathrm{Zr}$, Y, Hf, and $\mathrm{Ba}$, and low values of compatible elements) show similarities with tholeiitic, highly fractionated layered intrusions, and anorthosite-related ferrodiorite suites. However, the high Sc concentration of the Kiviniemi ferrodiorites (130-281 ppm) differs markedly from those in any of the other currently known rock types.

3. The intrusion shows textural evidence of mingling with a megacrystic granite, which is representative of postkinematic Svecofennian granitoids. Together, the granite and the mafic body form a bimodal association typical of the magmatism of the $1.88-1.87$ Ga post-kinematic stage of the Svecofennian orogeny.

4. U-Pb zircon ages of the ferrodiorite $(1857 \pm 2 \mathrm{Ma})$ and the megacrystic granite $(1860 \pm 7 \mathrm{Ma})$ show that these rocks are coeval and also younger than the post-kinematic mafic rocks and the surrounding rock units in the eastern CFGC. The initial $\varepsilon N d$ value of the ferrodiorite $(+0.1)$ is typical of the mafic intrusions of the CFGC, but the megacrystic granite $(\varepsilon \mathrm{Nd}-2.5)$ seems to show minor involvement of an Archaean crustal component. A co-magmatic origin for the ferrodiorite and the surrounding granite seems unlikely.

5. Before the onset of crystallization, Sc was enriched in the mafic magma by stabilization of fluoride and phosphate complexes; this may have controlled the behavior of Sc also during completion of crystallization.

6. The resource estimation calculated for Kiviniemi intrusion by using $40 \mathrm{~g} / \mathrm{t} \mathrm{Sc}$ cut off value is $13.4 \mathrm{Mt}$ of rock with an average grade of $162.7 \mathrm{~g} / \mathrm{t}$ scandium, $1726 \mathrm{~g} / \mathrm{t}$ zirconium, and $81 \mathrm{~g} / \mathrm{t}$ yttrium.

Acknowledgments The material presented in this paper were provided by the GTK and the research work were partly supported by K.H. Renlund Foundation (doctoral grant to M.A.). The personnel of the GTK Research Laboratory (Ms. Leena Järvinen, Mr. Arto Pulkkinen, Mr. Pekka Simelius, Mr. Bo Johanson, and Mr. Lassi Pakkanen, in particular) are greatly acknowledged for their work and help with the zircon 
sample preparation and isotope system measurements as well as microanalyses and preliminary interpretation of the raw data. The authors are grateful to Prof. J.-C. Duchesne and Prof. Andrew Kerr for comments on the first submission of the manuscript. As well as we would like to thank the two anonymous reviewers of Mineralium Deposita for valuable comments that greatly improved the manuscript and Petri Peltonen for editorial handling of the manuscript. Fruitful discussions and reviews of an early version of the manuscript by Dr. Esa Heilimo and Dr. Perttu Mikkola are highly appreciated. Peter Sorjonen-Ward is thanked for checking the English and Mrs. Riitta Turunen for help in graphics.

Open Access This article is licensed under a Creative Commons Attribution 4.0 International License, which permits use, sharing, adaptation, distribution and reproduction in any medium or format, as long as you give appropriate credit to the original author(s) and the source, provide a link to the Creative Commons licence, and indicate if changes were made. The images or other third party material in this article are included in the article's Creative Commons licence, unless indicated otherwise in a credit line to the material. If material is not included in the article's Creative Commons licence and your intended use is not permitted by statutory regulation or exceeds the permitted use, you will need to obtain permission directly from the copyright holder. To view a copy of this licence, visit http://creativecommons.org/licenses/by/4.0/.

\section{References}

Åmli R (1977) Carbonatites, a possible source of scandium as indicated by Sc mineralization in the Fen Paralkaline complex, southern Norway. Econ Geol 72:855-859

Baltybaev SK (2013) Svecofennian orogen of the Fennoscandian shield: compositional and isotopic zoning and its tectonic interpretation. Geotectonics 47:452-464

Barnes SJ, Makkonen HV, Dowling SE, Hill RET, Peltonen P (2009) The $1.88 \mathrm{Ga}$ Kotalahti and Vammala nickel belts, Finland: geochemistry of the mafic and ultramafic metavolcanic rocks. Bull Geol Soc Finl $81: 103-141$

Belousova E, Griffin W, O'Reilly S, Fisher N (2002) Igneous zircon: trace element composition as an indicator of source rock type. Contrib Mineral Petrol 143:602-622

Bergstøl S, Juve G (1988) Scandian ixiolite, pyrochlore and bazzite in granite pegmatite in Terdal, Telemark, Norway. A contribution to the mineralogy and geochemistry of scandium and tin. Mineral Petrol 38:229-243

Bernhard F (2001) Scandium mineralization associated with hydrothermal lazulite-quartz veins in the Lower Austroalpine Grobgneis complex, eastern Alps, Austria. Mineral Deposits at the Beginning of 21st Century: 935-938

Bernhard F, Walter F, Ettinger K, Taucher J, Mereiter K (1998) Pretulite, $\mathrm{ScPO}_{4}$, a new scandium mineral from the Styrian and Lower Austrian lazulite occurrences, Austria. Am Mineral 83:625-630

Bhattacharya A, Raith M, Hoernes S, Banerjee D (1998) Geochemical evolution of the massif-type anorthosite complex at Bolangir in the eastern Ghats Belt of India. J Petrol 39:1169-1195

Bowen NL (1928) The evolution of the igneous rocks. Princeton University press, Princeton, p 332

Boynton WV (1984) Cosmochemistry of the rare earth elements: meteoric studies. Rare Earth Elem Geochem 63-114

Brooks CK (1969) On the distribution of zirconium and hafnium in the Skaergaard intrusion, East Greenland. Geochim Cosmochim Acta $33: 357-374$
Carr JC, Beatson RK, Cherrie JB, Mitchell TJ, Fright WR, MCcallum JE, Evans TR (2001) Reconstruction and representation of 3D objects with radial basis functions. In: SIGGRAPH Computer Graphics Proceedings

Charlier B, Grove TL (2012) Experiments on liquid immiscibility along tholeiitic liquid lines of descent. Contrib Mineral Petrol 164:27-44

Charlier B, Sakoma E, Sauvé M, Stanaway K, Auwera JV, Duchesne J (2008) The grader layered intrusion (Havre-Saint-Pierre anorthosite, Quebec) and genesis of nelsonite and other Fe-Ti-P ores. Lithos 101:359-378

Charlier B, Namur O, Toplis MJ, Schiano P, Cluzel N, Higgins MD, Vander Auwera J (2011) Large-scale silicate liquid immiscibility during differentiation of tholeiitic basalt to granite and the origin of the Daly gap. Geology 39:907-910

Daigle PJ (2017) NI 43-101 technical report on the crater Lake Sc-NbREE project Québec, Canada. Prepared for: peak mining corporation, NQ exploration Inc and Imperial Mining Group Ltd. P. Daigle consulting services, $68 \mathrm{pp}$

DePaolo DJ (1981) Neodymium isotopes in the Colorado Front Range and crust-mantle evolution in the Proterozoic. Nature 291:193-196

DePaolo DJ, Wasserburg GJ (1976) Nd isotopic variations and petrogenetic models. Geophys Res Lett 3:249-252

Eby GN (1975) Abundance and distribution of the rare-earth elements and yttrium in the rocks and minerals of the Oka Carbonatite complex, Quebec. Geochim Cosmochim Acta 39:597-620

Eklund O, Konopelko D, Rutanen H, Fröjdö S, Shebanov AD (1998) $1.8 \mathrm{Ga}$ Svecofennian post-collisional shoshonitic magmatism in the Fennoscandian shield. Lithos 45:87-108

Elliott BA (2003) Petrogenesis of the post-kinematic magmatism of the Central Finland Granitoid complex II: sources and magmatic evolution. J Petrol 44:1681-1701

Elliott BA, Rämö OT, Nironen M (1998) Mineral chemistry constraints on the evolution of the 1.88-1.87 Ga post-kinematic granite plutons in the Central Finland Granitoid complex. Lithos 45:109-129

Fenner CN (1929) The crystallization of basalts. Am J Sci 5:225-253

Foord EE, Birmingham SD, Demartin F, Pilati T, Gramaccioli CM, Lichte FE (1993) Thortveitite and associated Sc-bearing minerals from Ravalli County, Montana. Can Mineral 31:337-346

Gramaccioli CM, Diella V, Demartin F (2000) The formation of scandium minerals as an example of the role of complexes in the geochemistry of rare earths and HFS elements. Eur J Mineral 12:795-808

Halkoaho T, Niskanen M (2015) Tutkimustyöselostus Rautalammin kunnassa valtausalueella Kiviniemi 1 (kaivosrekisterinumero 8777/1) suoritetuista skandium- ja zirkoniumesiintymätutkimuksista vuosina 2008-2010. Geological Survey of Finland, Report 56/2015, 32 pp (in Finnish)

Haskin LA, Haskin MA (1968) Rare-earth elements in the Skaergaard intrusion. Geochim Cosmochim Acta 32:433-447

Heaman LM, Bowins R, Crocket J (1990) The chemical composition of igneous zircon suites: implications for geochemical tracer studies. Geochim Cosmochim Acta 54:1597-1607

Heinonen AP, Andersen T, Rämö OT (2010) Re-evaluation of rapakivi petrogenesis: source constraints from the $\mathrm{Hf}$ isotope composition of zircon in the rapakivi granites and associated mafic rocks of southern Finland. J Petrol 51:1687-1709

Hess P, Rutherford M, Guillemette R, Ryerson F, Tuchfeld H (1975) Residual products of fractional crystallization of lunar magmas-an experimental study. Lunar Planet Sci Conf Proc 6:895-909

Hokka J, Halkoaho T (2016) 3D modelling and mineral resource estimation of the Kiviniemi Scandium deposit, Eastern Finland. Geological Survey of Finland, Report 65/2015, 16 pp and 5 App

Hoskin PWO, Ireland TR (2000) Rare earth element chemistry of zircon and its use as a provenance indicator. Geology 28:627-630 
Huhma H (1986) Sm-Nd, U-Pb and $\mathrm{Pb}-\mathrm{Pb}$ isotopic evidence for the origin of the early Proterozoic Svecokarelian crust in Finland. Geol Surv Finl Bull 33752 pp

Huhma H, Mänttäri I, Peltonen P, Kontinen A, Halkoaho T, Hanski E, Hokkanen T, Hölttä P, Juopperi H, Konnunaho J, Lahaye Y, Luukkonen E, Pietikäinen K, Pulkkinen A, Sorjonen-Ward P, Vaasjoki M, Whitehouse M (2012a) The age of the Archaean greenstone belts in Finland. In: Hölttä P (ed) The Archaean of the Karelia Province in Finland. Geol Surv Finl Spec Pap 54:74-175

Huhma H, Kontinen A, Mikkola P, Halkoaho T, Hokkanen T, Hölttä P, Juopperi H, Konnunaho J, Luukkonen E, Mutanen T, Peltonen P, Pietikäinen K, Pulkkinen A (2012b) Nd isotopic evidence for Archaean crustal growth in Finland. In: Hölttä P (ed) The Archaean of the Karelia Province in Finland. Geol Surv Finl Spec Pap 54:176-213

Irvine TN, Baragar WRA (1971) A guide to the chemical classification of the common volcanic rocks. Can J Earth Sci 8:523-548

Jaireth S, Hoatson DM, Miezitis Y (2014) Geological setting and resources of the major rare-earth-element deposits in Australia. Ore Geol Rev 62:72-128

Jakobsen JK, Veksler IV, Tegner C, Brooks CK (2005) Immiscible ironand silica-rich melts in basalt petrogenesis documented in the Skaergaard intrusion. Geology 33:885-888

Jakobsen JK, Veksler IV, Tegner C, Brooks CK (2011) Crystallization of the Skaergaard intrusion from an emulsion of immiscible iron- and silica-rich liquids: evidence from melt inclusions in plagioclase. $\mathrm{J}$ Petrol 52:345-373

Kärkkäinen N, Appelqvist H (1999) Genesis of a low-grade apatiteilmenite-magnetite deposit in the Kauhajärvi gabbro, western Finland. Mineral Deposita 34:754-769

Kärkkäinen NK, Bornhorst TJ (2003) The Svecofennian gabbro-hosted Koivusaarenneva magmatic ilmenite deposit, Kälviä, Finland. Mineral Deposita 38:169-184

Kontak DJ, De Wolfe De Young MY, Dostal J (2002) Late-stage crystallization history of the Jurassic North Mountain basalt, Nova Scotia, Canada. I. Textural and chemical evidence for pervasive development of silicate-liquid immiscibility. Can Mineral 40:1287-1311

Kontinen A, Huhma H, Lahaye Y, O'Brien H (2013) New U-Pb zircon age, Sm-Nd isotope and geochemical data on Proterozoic granitic rocks in the area west of the Oulunjärvi Lake, Central Finland. Geol Surv Finl Rep Invest 198:70-74

Korja A, Lahtinen R, Nironen M (2006) The Svecofennian orogen: a collage of microcontinents and island arcs. Geol Soc Lond Mem 32:561-578

Kravchenko SM, Pokrovsky BG (1995) The Tomtor alkaline ultrabasic massif and related REE-Nb deposits, northern Siberia. Econ Geol 90:676-689

Lahtinen R, Huhma H (1997) Isotopic and geochemical constraints on the evolution of the 1.93-1.79 Ga Svecofennian crust and mantle in Finland. Precambrian Res 82:13-34

Lahtinen R, Johnston ST, Nironen M (2014) The Bothnian coupled oroclines of the Svecofennian orogen: a Palaeoproterozoic terrane wreck. Terra Nova 26:330-335

Liferovich RP, Subbotin VV, Pakhomovsky YA, Lyalina MF (1998) A new type of scandium mineralization in phoscorites and carbonatites of the Kovdor massif, Russia. Can Mineral 36:971-980

Ludwig KR (2003) Isoplot/ex 3. A Geochronological toolkit for Microsoft excel. Berkeley Geochronologicy center, special Publication 4

Mattinson JM (2005) Zircon U-Pb chemical abrasion ("CA-TIMS") method: combined annealing and multi-step partial dissolution analysis for improved precision and accuracy of zircon ages. Chem Geol 220:47-66
McBirney AR (1995) Mechanisms of differentiation of layered intrusions: evidence from the Skaergaard intrusion. J Geol Soc Lond 152:421-435

McBirney AR (1998) The Skaergaard layered series. Part V. Included trace elements. J Petrol 39:255-276

McBirney AR (2002) The Skaergaard layered series. Part VI. Excluded trace elements. J Petrol 43:535-556

McBirney AR, Nakamura Y (1974) Immiscibility in late-stage magmas of the Skaergaard intrusion. Carnegie Inst Wash Yearb 73:348-352

Mellini M, Merlino S, Orlandi P, Rinaldi R (1982) Cascandite and jervisite, two new scandium minerals from Baveno, Italy. Am Mineral 67:599-603

Mikkola P, Heilimo E, Halkoaho T, Käpyaho A (2014) Neoarchaean alkali enriched gabbros and diorites of the Karelian Province as part of the diversification of the plutonic activity. In: Eklund O, Kukkonen I, Skyttä P, Sonck-Koota P, Väisänen M, Whipp D (eds) Lithosphere 2014: eight symposium on structure, composition and evolution of the lithosphere in Fennoscandia. Institute of Seismology, University of Helsinki rep S-62: 61-64

Mitchell JN, Scoates JS, Frost CD, Kolker A (1996) The geochemical evolution of anorthosite residual magmas in the Laramie Anorthosite complex, Wyoming. J Petrol 37:637-660

Morse SA (2008) Compositional convection trumps silicate liquid immisciblity in layered intrusions: a discussion of 'liquid immiscibility and the evolution of basaltic magma' by Veksler et al, journal of petrology 48, 2187-2210. J Petrol 49:2157-2168

Murphy JB, Dostal J (2007) Continental mafic magmatism of different ages in the same terrane: constraints on the evolution of an enriched mantle source. Geology 35:335

Mutanen T (2011) Alkalikiviä ja appiniitteja. Raportti hankkeen Magmatismi ja malminmuodostus II toiminnasta 2002-2005. Geol Surv Finl Arc Rep 9/2011 pp 627 (English abstract)

Naslund HR (1983) The effect of oxygen fugacity on liquid immiscibility in iron-bearing silicate melts. Am J Sci 283:1034-1059

Neumann H (1961) The scandium content of some Norwegian minerals and the formation of thortveitite, a reconnaissance survey. Nor Geol Tidsskr 41:197-210

Nikkilä K (2016) Analog models of the lateral spreading of a thick threelayer crust - implications for the Svecofennian orogen in Finland. Åbo Akademi University. pp 50

Nironen M (1997) The Svecofennian orogen: a tectonic model. Precambrian Res 86:21-44

Nironen M, Elliott BA, Rämö OT (2000) 1.88-1.87 Ga post-kinematic intrusions of the Central Finland Granitoid complex: a shift from Ctype to A-type magmatism during lithospheric convergence. Lithos 53:37-58

Norman JC, Haskin LA (1968) The geochemistry of Sc: a comparison to the rare earths and Fe. Geochim Cosmochim Acta 32:93-108

Orlandi P, Pasero M, Vezzalini G (1998) Scandiobabingtonite, a new mineral from the Baveno pegmatite, Piemont, Italy. Am Mineral 83:1330-1334

Pääjärvi A (2000) Rautalammin ja Karttulan kartta-alueiden kallioperä. Summary: explanation to the maps of pre-quaternary rocks, sheets 3223 and 3224. Geological map of Finland 1:100 000. Geol Surv Finl

Pang K, Zhou M, Lindsley D, Zhao D, Malpas J (2008) Origin of Fe-Ti oxide ores in mafic intrusions: evidence from the Panzhihua intrusion, SW China. J Petrol 49:295-313

Patchett J, Kouvo O (1986) Origin of continental crust of 1.9-1.7 Ga age: $\mathrm{Nd}$ isotopes and $\mathrm{U}-\mathrm{Pb}$ zircon ages in the Svecokarelian terrain of South Finland. Contrib Mineral Petrol 92:1-12

Peltonen P (2005) Mafic-ultramafic intrusions of the Svecofennian orogen. In: Lehtinen M, Nurmi PA, Rämö OT (eds) Precambrian 
of Finland - a key to the evolution of the Fennoscandian shield. Elsevier, Amsterdam, pp 413-447

Pezzotta F, Diella V, Guastoni A (2005) Scandium silicates from the Baveno and Cuasso al Monte NYF-granites, southern Alps (Italy): mineralogy and genetic inferences. Am Mineral 90:1442-1452

Philpotts AR (1979) Silicate liquid immiscibility in tholeiitic basalts. J Petrol 20:99-118

Philpotts AR (1982) Compositions of immiscible liquids in volcanic rocks. Contrib Mineral Petrol 80:201-218

Postl W (1981) Kolbeckit, ein seltenes wasserhaltiges Scandium Phosphat aus dem Steinbruch in der Klause bei Gleichenberg, Steiermark. Mitt Abt Miner Landesmuseum Joanneum 49:23-29

Raade G, Ferraris G, Gula A, Ivaldi G, Bernhard F (2002) Kristiansenite, a new calcium-scandium-tin sorosilicate from granite pegmatite in Tørdal, Telemark, Norway. Mineral Petrol 75:89-99

Raith M, Bhattacharya A, Hoernes S (1997) A HFSE- and REE-enriched ferrodiorite suite from the Bolangir Anorthosite Complex, Eastern Ghats Belt, India. Proc Indian Acad Sci Earth Planet Sci 106:299 311

Rämö OT (1986) Honkajoen Perämaan emäksinen intruusio - erityisesti sen gabro-osien petrografia, mineralogia ja petrologia. MSc thesis, University of Helsinki, Finland, pp 104 (in Finnish)

Rämö OT, Huhma H, Kirs J (1996) Radiogenic isotopes of the Estonian and Latvian rapakivi granite suites: new data from the concealed Precambrian of the East European Craton. Precambrian Res 79: 209-226

Rämö OT, Vaasjoki M, Mänttäri I, Elliott BA, Nironen M (2001) Petrogenesis of the post-kinematic magmatism of the Central Finland Granitoid complex I: radiogenic isotope constraints and implications for crustal evolution. J Petrol 42:1971-1993

Rasilainen K, Lahtinen R, Bornhorst TJ (2007) The rock geochemical database of Finland manual. Geol Surv Finl Rep Invest 164:38

Roedder E (1978) Silicate liquid immiscibility in magmas and in the system $\mathrm{K}_{2} \mathrm{O}-\mathrm{FeO}-\mathrm{AI}_{2} \mathrm{O}_{3}-\mathrm{SiO}_{2}$ : an example of serendipity. Geochim Cosmochim Acta 42:1597-1617

Rutanen H, Andersson UB, Väisänen M, Johansson Å, Fröjdö S, Lahaye Y, Eklund O (2011) 1.8 Ga magmatism in southern Finland: strongly enriched mantle and juvenile crustal sources in a post-collisional setting. Int Geol Rev 53:1622-1683

Shand SJ (1943) Eruptive rocks. Their genesis, composition, classification, and their relation to ore-deposits with a chapter on meteorite. John Wiley \& Sons, New York

Shchekina TI, Gramenitskii EN (2008) Geochemistry of Sc in the magmatic process: experimental evidence. Geochem Int 46:351-366

Shimazaki H, Yang Z, Miyawaki R, Shigeoka M (2008) Scandiumbearing minerals in the Bayan Obo Nb-REE-Fe deposit, Inner Mongolia, China. Resour Geol 58:80-86
Steiger RH, Jäger E (1977) Subcommission on geochronology: convention on the use of decay constants in geo- and cosmochronology. Earth Planet Sci Lett 36:359-362

Thy P, Lesher CE, Nielsen TFD, Brooks CK (2006) Experimental constraints on the Skaergaard liquid line of descent. Lithos 92:154-180

Tollari N, Toplis MJ, Barnes S (2006) Predicting phosphate saturation in silicate magmas: an experimental study of the effects of melt composition and temperature. Geochim Cosmochim Acta 70:15181536

Tollari N, Barnes S, Cox RA, Nabil H (2008) Trace element concentrations in apatites from the Sept-Îles intrusive suite, Canada - implications for the genesis of nelsonites. Chem Geol 252:180-190

Toplis MJ, Carroll MR (1996) Differentiation of ferro-basaltic magmas under conditions open and closed to oxygen: implications for the Skaergaard intrusion and other natural systems. J Petrol 37:837-858

Toplis MJ, Libourel G, Carroll MR (1994) The role of phosphorus in crystallisation processes of basalt: an experimental study. Geochim Cosmochim Acta 58:797-810

Vaasjoki M, Sakko M (1988) The evolution of the Raahe-Ladoga zone in Finland: isotopic constraints. Geol Surv Finl Bull 343:7-32

VanTongeren JA, Mathez EA (2012) Large-scale liquid immiscibility at the top of the Bushveld Complex, South Africa. Geology 40:491494

Veksler IV (2009) Extreme iron enrichment and liquid immiscibility in mafic intrusions: experimental evidence revisited. Lithos 111:72-82

Veksler IV, Dorfman AM, Borisov AA, Wirth R, Dingwell DB (2007) Liquid immiscibility and the evolution of basaltic magma. J Petrol 48:2187-2210

Veksler IV, Dorfman AM, Borisov AA, Wirth R, Dingwell DB (2008) Liquid immiscibility and evolution of basaltic magma: reply to S.A. Morse, A.R. McBirney and A.R. Philpotts. J Petrol 49:2177-2186

Wager LR, Deer WA (1939) Geological investigations in East Greenland, part III. The petrology of the Skaergaard intrusion, Kangerdlugssuaq, East Greenland. The petrology of the Skaergaard intrusion, Kangerdlugsssuk, East Greenland. Medd Gronl 105:1-352

White CM (2007) The graveyard point intrusion: an example of extreme differentiation of Snake River plain basalt in a shallow crustal pluton. J Petrol 48:303-325

Wiebe RA (1997) Fe-rich tholeiitic liquids and their cumulate products in the Pleasant Bay layered intrusion, coastal Maine. Contrib Mineral Petrol 129:255-267

Publisher's note Springer Nature remains neutral with regard to jurisdictional claims in published maps and institutional affiliations. 